\title{
Effects of short-term environmental disturbances on living benthic foraminifera during the Pacific oyster summer mortality in the Marennes- Oléron Bay (France)
}

\author{
Vincent M.P. Bouchet ${ }^{\mathrm{a}, \mathrm{b},{ }^{*}}$, Jean-Pierre Debenay, ${ }^{\mathrm{c},}$, Pierre-Guy Sauriau $^{\mathrm{a}}$, \\ Joël Radford-Knoery ${ }^{\mathrm{d}}$ and Patrick Soletchnik ${ }^{\mathrm{e}}$
}

\begin{abstract}
${ }^{a}$ CRELA (UMR 6217 CNRS-IFREMER-ULR), Centre de Recherche sur les Ecosystèmes Littoraux Anthropisés, Place du Séminaire, B.P. 5, 17137, L'Houmeau, France

bLaboratoire BIAF (UPRES EA 2644 Université d'Angers), Laboratoire d'étude des bio-indicateurs actuels et fossiles, 2 Bd Lavoisier, 49045, Angers cedex, France 'IRD, UR055 Paleotropique, Centre de Nouméa, BP A5, 98848, Nouméa cedex, New Caledonia

dIFREMER, Centre de Nantes, Département Biogéochimie et Ecotoxicologie, B.P. 21105, 44311, Nantes, France e IFREMER, Laboratoire Environnement et Ressources Poitou-Charentes (LERPC), B.P. 133, 17390, La

Tremblade, France

*: Corresponding author : vincent.bouchet@ifremer.fr
\end{abstract}

\begin{abstract}
:
Sediment cores were collected from April to August 2004 on tidal mudflats of the macrotidal Marennes-Oléron Bay (SW France), famous for the cultivation of Pacific oysters (Crassostrea gigas). The response of living (stained) benthic foraminifera to short-term biogeochemical disturbances in the sediment and overlying water, which may be involved in oyster summer mortality, was monitored. Short-term hypoxia occurred in early June, in conjunction with a sudden rise in temperature. In midJune, the ammonia content of sediment porewater increased, leading to potentially maximal flux towards overlying waters. Foraminiferal assemblages, particularly in the topmost layer, were altered. Ammonia tepida was the most tolerant to temperature increase and hypoxic conditions whereas Brizalina variabilis and Haynesina germanica were sensitive to organic degradation and hypoxia. Cribroelphidium gunteri was the most opportunistic during recolonisation. Benthic foraminifera showed that short-term biochemical changes in the sediment are toxic and may be involved in the summer mortality of Pacific oysters.
\end{abstract}

Keywords: Living benthic foraminifera; Organic matter; Hypoxia; Ammonium; Intertidal; Crassostrea gigas; Aquaculture; Marennes-Oléron bay 


\begin{abstract}
Sediment cores were collected from April to August 2004 on tidal mudflats of the macrotidal Marennes-Oléron Bay (SW France), famous for the cultivation of Pacific oysters (Crassostrea gigas). The response of living (stained) benthic foraminifera to short-term biogeochemical disturbances in the sediment and overlying water, which may be involved in oyster summer mortality, was monitored. Short-term hypoxia occurred in early June, in conjunction with a sudden rise in temperature. In mid-June, the ammonia content of sediment porewater increased, leading to potentially maximal flux towards overlying waters. Foraminiferal assemblages, particularly in the topmost layer, were altered. Ammonia tepida was the most tolerant to temperature increase and hypoxic conditions whereas Brizalina variabilis and Haynesina germanica were sensitive to organic degradation and hypoxia. Cribroelphidium gunteri was the most opportunistic during recolonisation. Benthic foraminifera showed that short-term biochemical changes in the sediment are toxic and may be involved in the summer mortality of Pacific oysters.
\end{abstract}

\title{
Keywords
}

Living benthic foraminifera - organic matter - hypoxia - ammonium - intertidal Crassostrea gigas - aquaculture - Marennes-Oléron Bay 


\section{Introduction}

In many parts of the world, including Japan, North America and North-western Europe, mass mortality affects the Pacific oyster Crassostrea gigas (Thunberg) (Imaï, Numachi, Oizumi \& Sato, 1965; Glude, 1974; Maurer, Comps \& His, 1986; Soletchnik, Le Moine, Faury, Razet, Geairon \& Goulletquer, 1999; Cheney, MacDonald \& Elston, 2000). Along the French coasts of the Atlantic and English Channel, summer mortality was first reported from the Arcachon Bay during the early 1980s (Maurer et al., 1986), and since then from most shellfish production areas (Costil, Royer, Ropert, Soletchnik \& Mathieu, 2005; Dégremont, Bedier, Soletchnik, Ropert, Huvet, Moal et al., 2005; Soletchnik, Lambert \& Costil, 2005). A number of studies have established that summer mortality not only occurs during periods of physiological stress associated with gonad development and maturation, but it is also driven by complex interactions between environmental factors and oyster-farming practices. For example, in Marennes-Oléron Bay, daily mortality rates of "on-bottom" oysters, reared directly on the intertidal sediments, were significantly higher than those of "off-bottom" oysters reared on trestles (Soletchnik et al., 1999; Soletchnik et al., 2005; Gagnaire, Soletchnik, Madec, Geairon, Le Moine \& Renault, 2006). These observations provide circumstantial support for the idea that intertidal muddy sediments play a role in the summer mortality of Pacific oysters (Soletchnik et al., 1999; Soletchnick et al., 2005; Gagnaire et al., 2006). As reported for blue mussel farming (e.g. Grant, Hatcher, Scott, Pocklington, Schafer \& Winters, 1995; Ragnarsson \& Raffaelli, 1999; Christensen, Glud, Dalsgaard \& Gillespie, 2003; Hartstein \& Rowden, 2004), the properties of soft-sediments beneath oyster cultivation sites are modified by significant organic enrichment due to biodeposition of faeces and pseudofaeces, and sedimentation of silt (Sornin, Feuillet, Héral \& Deslous-Paoli, 1983; Nugues, Kaiser, Spencer \& Edwards, 1996; Mallet, Carver \& Landry, 2006). Driven by seasonal and tidal cycles, simultaneous increase in temperature, availability of organic 
biodeposits, and varying oxidation levels in the surface sediment can lead to active mineralisation of sedimentary organic matter. This phenomenon favours geochemical cycling within the sediments, with a complex balance between aerobic and anaerobic processes (Sornin et al., 1983; Lerat, Boucher \& Le Corre, 1985; Feuillet-Girard, Héral, Sornin, Deslous-Paoli, Robert, Mornet et al., 1988; Santschi, Höhener, Benoit \& Buchholtz-ten Brink, 1990). On some occasions, back-diffusion of released toxic nutrients such as ammonia and sulphur to the water column may occur (Sornin et al., 1983; Feuillet-Girard et al., 1988; Santschi et al., 1990; Vouvé, Guiraud, Marol, Girard, Richard \& Laima, 2000; Gray, Wu \& Or, 2002). Physicochemical and geochemical changes resulting from the input of organic deposits associated with oyster cultivation influence benthic communities and can modify species richness and distribution patterns of soft-bottom macrofauna (Castel, Labourg, Escaravage, Auby \& Garcia, 1989; Nugues et al., 1996; Deslous-Paoli, Souchu, Mazouni, Juge \& Dagault, 1998) and meiofauna (Castel et al., 1989; Dinet, Sornin, Sablière, Delmas \& Feuillet-Girard, 1990). Although benthic foraminifera have been used successfully as biological indicators to assess the status of various pristine or polluted ecosystems (Alve, 1995a, b; Grant et al., 1995; De Rijk, Jorissen, Rohling \& Troelstra, 2000; Annin, 2001; Debenay, Tsakiridis, Soulard \& Grossel, 2001; Alve, 2003; Morvan, Le Cadre, Jorissen \& Debenay, 2004; Debenay, Bicchi, Goubert \& Armynot du Châtelet, 2006), only a few studies have been carried out on benthic foraminifera related specifically to aquaculture. The main ones are those carried out in Atlantic Canada by Schafer, Winters, Scott, Pocklington, Cole \& Honig (1995) and Scott, Schafer, Honig \& Younger (1995), related to blue mussel and salmon aquaculture respectively, and in the Red Sea by Angel, Verghese, Lee, Saleh, Zuber, Lindell et al. (2000), which was related to fish farming. As far as we know, temporal variations of benthic foraminiferal assemblages associated with oyster cultivation have never been described. It is well established that foraminifera responses, such as changes in species 
richness, dominance of calcareous vs. agglutinated species, specific depth distribution and test morphology, are related to environmental parameters. Among the factors reported to affect foraminiferal assemblages, both oxygen availability and organic matter fluxes are regarded as major structuring forces acting on benthic foraminifera in marine environments (van der Zwaan, Duijnstee, den Dulk, Ernst, Jannink \& Kouwenhoven, 1999; De Rijk et al., 2000; den Dulk, Reichart, van Heyst, Zachariasse \& van der Zwaan, 2000; Ernst, Bours, Duijnstee \& van der Zwaan, 2005).

In the present study, changes in living (stained) benthic foraminiferal assemblages were analysed and compared with temporal changes in the properties of intertidal sediments influenced by Pacific oyster cultivation during a critical period in spring/summer oyster mortality. The parameters taken into account were the concentration in sedimentary organic matter, dissolved ammonia and sulfide dynamics within the sediment porewaters and the hydrology (temperature, salinity, turbidity and oxygen saturation) of the overlying waters. The aim of the study was to use the rapid response of foraminiferal assemblages to environmental parameters in order to assess the impact of physiochemical changes on benthic communities.

\section{Materials and methods}

\subsection{Site location and survey design}

The study was carried out at Ronce-Perquis, an intertidal oyster cultivation area located in the southern part of Marennes-Oléron Bay, on the French Atlantic coast north of the Gironde estuary (Fig. 1). Experiments were performed in an oyster park subject to 50-65\% immersion, i.e. emergent at low tide when the tidal coefficient is over 60-70. Tidal coefficients range from 20 to 120 according to SHOM (Service Hydrographique de la Marine, Brest), corresponding to extreme neap tides and extreme spring tides, respectively. Pacific oysters 
Crassostrea gigas were reared in plastic mesh bags placed on trestles at 70 and $15 \mathrm{~cm}$ above the sediment surface, hereafter called "off-bottom" and "on-bottom" culture, respectively. The initial rearing density was set at 200 oysters per bag, and mortality rates were estimated by counting dead and live specimens at each sampling date.

Soletchnick et al. (1999), in their study on dynamics of oyster mortality at the same site, reported that the oyster mortalities are seasonal, occurring during spring and summer. The period selected for the study of temporal variations in water column parameters, sediment properties and foraminiferal assemblages was chosen on the basis of this previous study. Samples were collected between 22 April (before the beginning of oyster mortality) and 4 August 2004 (several weeks after the mid-June, mortality maximum). Sediments were analysed on 22 April, 6 and 25 May, 9, 14, 22 and 30 June and 4 August, and foraminiferal assemblages collected on 22 April, 25 May, 9 and 22 June, and 4 August.

Figure 1

\subsection{Bottom water characteristics}

A YSI multiparameter probe was deployed $15 \mathrm{~cm}$ above the sediment surface of the oyster cultivation site. The YSI probe measured temperature, salinity, oxygen content and turbidity (measured in Nephelometric Turbidity Units, NTU) continuously for 2 min every 15 min from April to August 2004.

\subsection{Sediment temperature and biochemistry}

Two temperature loggers (StowAway TidbiT, ONSET) were deployed at the water-sediment interface and at $15 \mathrm{~cm}$ sediment depth. Both were set to measure temperature every $10 \mathrm{~min}$ for the entire study period. Furthermore, on each sampling date, in situ sediment temperature, $\mathrm{pH}$ and redox levels were determined using a Cyberscan $\mathrm{pH} 300$ series probe (EUTECH Instruments) at 1 and $4 \mathrm{~cm}$ below the water-sediment surface of sediment cores sampled at 
low tide. Measurements were made immediately through $1 \mathrm{~cm}$-spaced holes predrilled into the core tube.

For organic matter analyses, the top of two sediment cores (diameter $=73 \mathrm{~mm}$ ) was sliced off in two layers $(0-1 \mathrm{~cm}$ and $1-2 \mathrm{~cm})$ and each one homogenized. One sub-sample of sediment organic matter (SOM) was analysed for particulate organic carbon and nitrogen (POC and PON) using a $\mathrm{C} / \mathrm{N}$ analyser (Carlo Erba NA 1500), and carbon and nitrogen stable isotopes $\left(\delta^{13} \mathrm{C}\right.$ and $\left.\delta^{15} \mathrm{~N}\right)$ following procedures described by Riera, Richard, Grémare \& Blanchard (1996). Carbon and nitrogen stable isotopes were analysed using a mass spectrometer (Micromass, Manchester, UK) interfaced to an elemental analyser EuroEA3024-IRMS (Eurovector, Milan, Italy). Data were expressed in the standard $\delta$ notation as parts per thousand (\%) relative to the Peedee Belemnite Limestone (PDB) and atmospheric $\mathrm{N}_{2}$ for carbon and nitrogen, respectively. Replicate analyses of SOM show a standard deviation of $0.1 \%$ for both $\mathrm{C}$ and $\mathrm{N}$ isotope ratios, which was small, compared to between-sample variability (Bouchet \& Sauriau, unpub. data). The top $1 \mathrm{~cm}$ sediment chlorophyll $a(\mathrm{chl} a)$ and phaeopigment concentrations were determined following Lorenzen's method (Holm-Hansen, Lorenzen, Holmes \& Strickland, 1965). Two subsamples were freeze-dried, extracted overnight in $90 \%$ acetone $\left(4^{\circ} \mathrm{C}\right)$, centrifuged $10 \mathrm{~min}$ at $2000 \mathrm{rpm}$, analyzed spectrophotometrically (Turner $10 \mathrm{AU}$ ), and corrected for phaeopigments, which were determined after 1N HCl treatment (Yentsch \& Menzel, 1963).

For dissolved ammonia $\left(\mathrm{NH}_{4}{ }^{+}\right.$and $\left.\mathrm{NH}_{3}\right)$ and sulfide $\left(\mathrm{H}_{2} \mathrm{~S}\right)$ analyses in pore water, $73 \mathrm{~mm}$ diameter transparent acrylic tubes, were used to retrieve $20 \mathrm{~cm}$ long sediment cores. Immediately after sample collection, porewater extraction began. Predilled $1 \mathrm{~cm}$-spaced holes in the core tube covered with electrical tape allowed easy insertion of glass-fibre reinforced Rhizon in situ samplers (RISS, described in Seeberg-Elverfeldt, Schlüter, Feseker \& Kölling, 2005). A maximum of $2 \mathrm{ml}$ of porewater $(0.1 \mu \mathrm{m}$-filtered by the RISS) was then vacuum 
extracted at each sampling depth using $2.5 \mathrm{ml}$ polyethylene syringes tipped with Luer-Lock 3way valves. Once the extraction was complete (10 to $30 \mathrm{~min}$.), the syringes were then used to dispense the appropriate amount of sample into polyethylene test tubes and analyses carried out immediately. The RISS devices are particularly convenient because the entire sample collection process is conducted without atmospheric contact and hence adverse effects on sulfide or ammonia oxidation. Commercially available reagents (Merck Ammonium ref 1.14752 and Merck Sulfide ref 1.14779) were used to determine sulfide and ammonia. The methods are based the well-known methylene blue (e.g., Cline, 1969) and indophenol reactions (e.g., Solorzano, 1969). The amounts of the reagents used for each analysis were scaled to the sample volume. External calibrations were carried out using an aqueous matrix identical to that of the sample but ammonium- and sulfide-free in order to avoid for any potential interference in the chemical reactions involved. Sulfide determinations were performed on undiluted porewaters, whereas ammonia samples were diluted with ultrapure water 5- to 20-fold before analysis. Reported concentrations are well above the detection limits, and precision is estimated to be $10 \%$ or better, based on replicate analyses and on the calibration using linear, least squares regression fits.

\subsection{Samples for benthic foraminifera}

At each sampling date, the superficial sediment $(0-0.5 \mathrm{~cm})$ was scraped off over a $1-2 \mathrm{~m}^{2}$ surface, using a "pseudoreplication" procedure (Hurbert, 1984) that limits the potential bias due to the patchiness of foraminifera. In addition, one core was collected using a coring tube (8 $\mathrm{cm}$ long and $7.5 \mathrm{~cm}$ in diameter), capped on site and transported back to the lab for processing. The core was sliced into 5 segments i.e. $0-0.5 \mathrm{~cm}, 0.5-1 \mathrm{~cm}, 1-3 \mathrm{~cm}, 3-5 \mathrm{~cm}$ and $5-8 \mathrm{~cm}$ in order to describe the vertical distribution of benthic foraminifera. Each sample was preserved in $70 \%$ ethanol with $1 \mathrm{~g}^{-1}$ Rose Bengal for staining foraminifera in order to 
distinguish stained (living) from dead specimens (Murray \& Bowser, 2000). This study solely focused on living foraminifera as recommended by Murray (2000). After at least three days in the staining solution, samples were washed through $50 \mu \mathrm{m}$ mesh sieves and dried at $50^{\circ} \mathrm{C}$. After drying, tests were concentrated by heavy liquid flotation using carbon tetrachloride $\left(\mathrm{CCl}_{4}\right)$. Before examining foraminifera, each sample was split into two aliquots from which two counts were made. When necessary, the aliquots were divided again to give a maximum of approximately 2000 living specimens. These specimens were carefully spread over a picking tray with 42 cells. Cells were selected randomly and all the living specimens in each cell were picked and counted, until a total of at least 150 specimens, under a stereomicroscope (Leica MZ75). Only the living specimens were identified. Fatela \& Taborda (2002), in their study on the confidence limits of benthic foraminiferal counts, demonstrated that counts as low as 100 specimens are sufficient in studies based on the species representing at least $5 \%$ of the assemblage. For recognition of "living" specimens, opaque agglutinated and porcelaneous tests were completely soaked in the water, over a white bottom, to allow observation of stained cytoplasm to be made. Species were classified according to Loeblich and Tappan's ordinal classification (1988). Abundances were expressed as total number of living specimens in $50 \mathrm{~cm}^{3}$ of sediment and abundances of each stained species (number of living individuals in $50 \mathrm{~cm}^{3}$ of sediment) was determined. The relative abundance of stained foraminifera species within a sediment layer was calculated. The species richness was defined as the number of living (stained) species per 150 individuals within a sediment layer. At each sampling date, 40 living (stained) specimens of Ammonia tepida were randomly picked from the first two core layers i.e. $0-0.5$ and $0.5-1 \mathrm{~cm}$. The maximum diameter of their tests was measured in order to assess size frequency distributions of the A. tepida population.

\subsection{Data analysis}


Depth profile of ammonia and sulfide concentrations were mapped by kriging methods using Surfer 6 (Golden Software Inc.). Both data sets were fitted with linear variogram models, which incorporated anisotropy to take into account the higher continuity between data points located along the vertical axis.

Distribution patterns of living (stained) foraminifera abundances are represented by using rank-frequency diagrams (RFD). This technique relies on ranked frequencies of species plotted against their respective ranks organized in decreasing order, and with both axes in logarithmic scale (Legendre \& Legendre, 1984; Frontier, 1985). Ecological interpretation of RFDs was reviewed by Frontier (1985) in a comparison of mathematical models (Mouillot \& Lepretre, 2000). It relies on the recognition of 3 ecological succession stages associated with 3 different RFD curve shapes: linear-concave $=$ pioneer assemblage with low species richness (stage 1); convex = intermediate assemblage with increasing species diversity (stage 2) and straight-line $=$ mature assemblage (stage 3) (Fig. 7d). In some cases, a straight-line may reflect mixtures of different assemblages of intermediate diversity. The method was successfully applied to compare polluted vs. unpolluted macrobenthic assemblages (Hily, 1983) and to describe their long-term changes (e.g. Davoult, Dewarumez \& Migné, 1998). For example, ecological succession from pioneer assemblage to mature assemblage reveal a recovery in the assemblage (dotted arrow in Fig. 7d).

Student t-test for paired data was performed to evaluate the null hypothesis that total and specific foraminiferal abundances from surface sediments did not differ between sampling methods (i.e. pseudoreplication vs. core sampling). One-way and two-way ANOVA with replication and fixed effects were performed to test, for instance, the null hypothesis that temporal changes in environmental conditions of the sediments did not affect the abundances and depth distribution of the foraminiferal taxa. Prior to ANOVA analyses, species abundances were square-root transformed in order to improve equality of variances and 
normality (Zar, 1984). A Kolmogorov-Smirnov goodness of fit test (K-S test) was used to reveal any differences in size distribution frequencies in the Ammonia tepida population between the surface $(0-0.5 \mathrm{~cm})$ and the subsurface $(0.5-1 \mathrm{~cm})$ sediment layers. All statistical analyses were performed with Statistica v.7.1 or computed according to Zar (1984).

\section{Results}

\subsection{Variations in bottom water characteristics}

The salinity of the water over the oyster culture site ranged from 31 to 35 except during 5 days in early May, when values ranged from 25 to 30 . Although the turbidity of the bottom waters was lower than $100 \mathrm{NTU}$ most of the time, there were two periods with values higher than 900 NTU, i.e. on 12 May and between 26 May and 10 June (Fig. 2). During this last period, oxygen levels dropped to hypoxic conditions (20\% air-saturation) compared to normoxic conditions recorded before 26 May and after 10 June (Fig. 2).

Figure 2

\subsection{Variations in sediment temperature and oyster mortality}

Mean daily temperature at the sediment water interface increased from $13.3^{\circ} \mathrm{C}$ in April to $21.9^{\circ} \mathrm{C}$ in early August (Fig. 3). Increase in temperature was however discontinuous since two periods of sharp increase occurred, one in mid-May $\left(+4^{\circ} \mathrm{C}\right.$ in 6 days $)$ and the other in early June $\left(+4.0^{\circ} \mathrm{C}\right.$ in 10 days) (Fig. 3). During these two periods, the temperature range was the highest. This led to a difference of ca. $+12^{\circ} \mathrm{C}$ between the minimal and maximal daily temperature in a few days, in conjunction with an increase in the spring tide amplitude. The fact that periods of the highest day-to-day temperature variability coincide with extreme spring tides in Marennes-Oléron Bay results from the occurrence of extreme low spring tide at midday. From 15 June to 4 August, day-to-day variation in mean temperature was reduced and 
ranged from 19.2 to $21.9^{\circ} \mathrm{C}$ (Fig. 3). Variations in temperature at $15 \mathrm{~cm}$ depth followed similar trends but were smoother, the daily temperature amplitude being lower than $1.5^{\circ} \mathrm{C}$ (Fig. 3).

The highest daily mortality rates of oysters were observed from early to mid-June for both rearing conditions after mean temperature had reached $18-19^{\circ} \mathrm{C}$ on 5 June and day-to-day temperature reached its highest, $28^{\circ} \mathrm{C}$ on 7 June (Fig. 3). Daily mortality rates were always significantly higher for "on-bottom" than for "off-bottom" rearing conditions (two-way ANOVA results: $\mathrm{P}<0.01$ ) with maximum mortality rates of 0.43 day $^{-1}$ (Fig. 3). After a 6month rearing period, cumulative mortality was also significantly higher for "on-bottom" than for "off-bottom" conditions (Student $\mathrm{t}$ test results $\mathrm{P}<0.001$ ), with cumulative values of 14.8 \pm 2.9 and $5.7 \pm 0.9 \%$, respectively.

Figure 3

Table 1

\subsection{Variations in sediment characteristics}

The measures of sediment characteristics are found on Table 1.

Salinities recorded within intertidal sediment porewater ranged from 31 to 35 , similar to those of the overlying bottom water. The temperature of surface sediments (at $1 \mathrm{~cm}$ depth) was higher than that of subsurface sediment (at $4 \mathrm{~cm}$ depth) from June to August when both $\mathrm{pH}$ and Eh values were lower in surface than subsurface sediments. Respective ranges of $\mathrm{pH}$ and Eh were 6.9 to 8.0 and -112 to $-183 \mathrm{mV}$. For surface sediments, the lowest Eh was recorded on 22 June $(-160 \mathrm{mV})$ and then increased to $-112 \mathrm{mV}$ on 4 August.

Chlorophyll $a$ contents from the top $1 \mathrm{~cm}$ of the sediments continuously increased from early April to 9 June, suddenly dropped on 14 June and then increased again from the end of June to early August. Phaeopigments followed a similar trend with maximal values on 9 June $(>1500$ $\pm 700 \mathrm{mg} \mathrm{m}^{-2}$ ) followed by minimal values (ca $300 \pm 60 \mathrm{mg} \mathrm{m}^{-2}$ ) on $14 \mathrm{June}$. Chlorophyll $a$ 
and phaeopigments at 1-2 $\mathrm{cm}$ depth were always significantly lower than those of the top 1 $\mathrm{cm}$ of sediments (ANOVA results: $\mathrm{P}<0.001$ and $\mathrm{P}<0.01$ respectively) but exhibited similar seasonal changes. Particulate organic carbon (POC) and nitrogen (PON) also matched these seasonal variations with minimal values recorded on 14 June after maximal values on 9 June, whatever the sediment layers. Values of POC and PON recorded at the end of June and early August were similar or higher than those recorded on 9 June. $\mathrm{C} / \mathrm{N}$ ratios were relatively stable over the sampling period and ranged from 6.6 to 7.5. Similarly, $\delta^{13} \mathrm{C}$ and $\delta^{15} \mathrm{~N}$ values from the top $1 \mathrm{~cm}$ of sediments did not exhibit large variations and ranged from -20.5 to $-21.8 \%$ and 5.9 to $6.4 \%$, respectively.

Temporal changes in porewater profiles of ammonia and sulfide content within the sediment matrix revealed the occurrence of peak values in mid-June at 5-6 cm depth and in early July at a depth of $0.5 \mathrm{~cm}$, respectively (Figs. $4 \mathrm{a}, \mathrm{b}$ ). Maximum values of porewater ammonia content occurred from 14 to 22 June and extended through the entire sedimentary column on 14 June with a peak value of $45 \mathrm{mg} \mathrm{l}^{-1}$ (Fig. 4 a). A similar phenomenon occurred in porewater sulfide content on 30 June with a maximal value of $0.62 \mathrm{mg}^{-1}$ but this event occurred within a stable background content averaging 0.1-0.2 $\mathrm{mg}^{-1}$. It also came after a small peak, which started on 25 May at $1.5 \mathrm{~cm}$ and extended up to the sediment-water interface by 14 June (Fig. $4 b)$.

Figure 4

\subsection{Living (stained) foraminifera: species richness and abundances}

T-tests for paired data were performed to compare the pseudoreplication and core sampling protocols using results from surface sediments. Neither living (stained) foraminiferal species richness nor total and specific abundances of surface sediments varied significantly from one

method to the other (Table 2). Patchiness affects the results on one date but its effect is reduced on a long-term series of samples. 
Table 2

Thirty living (stained) species were determined (Appendix A). Species richness significantly varied by sampling date and depth (two-way ANOVA results: $\mathrm{P}<0.001)$ with maximum and minimum values recorded in surface and deep sediment layers, respectively (Fig. 5). On three dates, 25 May, 9 June and 4 August, species richness at $0.5-1 \mathrm{~cm}$ was significantly higher than that at $0-0.5 \mathrm{~cm}$ (Fig. 5).

Figure 5

Temporal changes in depth profiles of relative abundances were highly significant (two-way ANOVA results: $\mathrm{P}<0.001)$ and the lowest relative abundances of living foraminifera were recorded within the $1-3$ to $5-8 \mathrm{~cm}$ layers on 22 June. Living specimens were mainly concentrated within the topmost $1 \mathrm{~cm}$ of sediments (Fig. 5).

Temporal changes in abundances of living foraminifera were highly significant (two-way ANOVA results: $\mathrm{P}<0.001$ ) with a decrease by 50 to $65 \%$ in living specimens for both the 0 0.5 and $0.5-1 \mathrm{~cm}$ layers from early April to 9 June (Fig. 5). The abundance of living foraminifera for surface sediments $(0-0.5 \mathrm{~cm}$ depth $)$ had recovered by the end of June but that of subsurface sediments $(0.5-1 \mathrm{~cm}$ depth) did not and remained lower than initial values (Fig. $5)$.

Benthic foraminiferal assemblages were dominated by 6 species i.e. Ammonia tepida (Cushman), Brizalina striatula (Cushman), Cribroelphidium excavatum (Terquem), Cribroelphidium gunteri (Cole), Haynesina germanica (Ehrenberg) and Quinqueloculina seminula (Linné) (Appendix A). Four of these species (Ammonia tepida, Brizalina striatula, Cribroelphidium gunteri and Quinqueloculina seminula) exhibited higher abundances at depths of $0-0.5 \mathrm{~cm}$ than at $0.5-1 \mathrm{~cm}$ (Figs. $6 \mathrm{a}, \mathrm{b}, \mathrm{d}, \mathrm{f}$, two-way ANOVA results: $\mathrm{P}<0.001$ ). Ammonia tepida was the most abundant and comprised up to $76 \%$ of total abundance of stained species (Appendix A). Its abundances significantly decreased from 22 April to 9 June 
(Fig. 6a) (two-way ANOVA results: $\mathrm{P}<0.001$ ) in both 0-0.5 and 0.5-1 cm layers, with 46 and $41 \%$ of the total abundance of live specimens, respectively (Appendix A). The decrease of the abundance was however significantly higher within the $0.5-1 \mathrm{~cm}$ depth range (two-way ANOVA, results: $\mathrm{P}<0.001)$. On 22 June, the abundance of $A$. tepida was again above 7000 specimens per $50 \mathrm{~cm}^{-3}$ in surface sediments whereas it was lower than 3000 specimens per 50 $\mathrm{cm}^{-3}$ at $0.5-1 \mathrm{~cm}$ (Fig. 6a). At the end of the survey, the A. tepida abundance was still significantly higher at $0-0.5 \mathrm{~cm}$ than at $0.5-1 \mathrm{~cm}$ (two-way ANOVA results: $\mathrm{P}<0.001$ ). Haynesina germanica and Brizalina striatula were largely represented on 22 April in both the 0-0.5 and 0.5-1 cm layers (Figs. 6b, e) but their abundances significantly declined during the survey (two-way ANOVA results: $\mathrm{P}<0.001$ ). In contrast, Cribroelphidium excavatum exhibited significant peaks in density on 25 May in the $0-0.5 \mathrm{~cm}$ layer and on 22 June in the 0.5-1 cm layer (two-way ANOVA results: $\mathrm{P}<0.001$ ). On 22 June, C. excavatum was the dominant species in place of $A$. tepida in the $0.5-1 \mathrm{~cm}$ layer but its abundance on 4 August was lower than that on 22 April (Fig. 6c). At the end of the survey, Cribroelphidium gunteri became the second most dominant species after A. tepida in the $0-0.5 \mathrm{~cm}$ layer with a highly significant increase in density (two-way ANOVA results: $\mathrm{P}<0.001$ ).

Figure 6

\subsection{Structure of living (stained) foraminiferal assemblages}

From 22 April to 25 May, rank-frequency diagrams (RFDs) from topmost sediments (0-0.5 and $0.5-1 \mathrm{~cm}$ ) appeared as a straight line (Figs. 7a, b). On 9 June and 22 June, RFD appeared to be more convex and those of 4 August linear concave. All RFDs of deeper layers $(5-8 \mathrm{~cm})$ were convex and characterized by a lower species richness than those of surface sediments (Fig. 7c). From 22 April to 4 August, large changes in RFDs appeared for surface sediments due to changes in species richness and species dominance (Figs. 7a, b, Appendix A). On 22 April, Ammonia tepida, Brizalina striatula and Haynesina germanica dominated 
foraminiferal assemblages, composed of 14 species, in the $0-0.5 \mathrm{~cm}$ layer, and A. tepida, Cribroelphidium excavatum and B. striatula dominated the low-diversity foraminiferal assemblage, made up of only 8 species, in the $0.5-1 \mathrm{~cm}$ layer. Several species were absent from surface sediments on 9 June such as Bolivina pseudoplicata Heron-Allen \& Earland, Brizalina variabilis (Williamson), Fissurina lucida (Williamson), Massilina secans (d'Orbigny), Adelosina bicornis (Walter \& Jacob), Qinqueloculina jugosa Cushman, $Q$. seminula (which was the second most abundant species on 22 June), Reophax scorpiurus de Monfort, Rosalina cf. vilardeboana (d'Orbigny) and Spirillina vivipara Ehrenberg (only recorded on 22 April). In contrast, several species were recorded mainly on 9 June in surface sediments, such as Brizalina spathulata (Williamson), Bulimina elegans d'Orbigny and Eggerelloides scabrus (Williamson), the later being recorded earlier in both the 3-5 and the 5$8 \mathrm{~cm}$ layers on 22 April (Appendix A).

Foraminiferal assemblages from the 5-8 $\mathrm{cm}$ sediment layers were dominated equally by two species i.e. Ammonia tepida and Cribroelphidium excavatum, and this explained the more convex shape of the RFDs (Fig. 7c). The third most abundant species was C. gunteri, but on 9 and 22 June, $C$. gunteri was not recorded and was replaced by Haynesina germanica. From 22 April to 4 August, no differences in the shape of the RFDs from the 5-8 cm layers were apparent although a higher number of rare species was recorded on 22 April (Fig. 7c). The dominance by species reported on 22 April i.e. A. tepida, C. excavatum and C. gunteri was modified on 9 and 22 June but recovered on 4 August (Appendix A).

Figure 7

\subsection{Size-frequency distributions of Ammonia tepida}

Temporal changes in the size-frequency distributions of Ammonia tepida from both the 0-0.5 and the $0.5-1 \mathrm{~cm}$ layers are shown in Fig. 8. On 22 April, small individuals $(175-275 \mu \mathrm{m}$ in diameter) dominated the population in the $0-0.5 \mathrm{~cm}$ layer, whereas bigger specimens $(300-475$ 
$\mu \mathrm{m})$ were also abundant in the $0.5-1 \mathrm{~cm}$ layer (K-S test results: $\mathrm{P}<0.001)$. Over April and May, specimens grew and 425-500 $\mu \mathrm{m}$ specimens dominated both histograms from 25 May. However, these histograms significantly differed from each other due to a higher proportion of bigger specimens within surface sediments (K-S test results: $\mathrm{P}<0.001)$. Major mortalities occurred between the end of May and 9 June leading to size-frequency distributions between the two sediment layers becoming homogeneous $(\mathrm{K}-\mathrm{S}$ test results: $\mathrm{P}=0.23)$. At the end of June, size-frequency distributions of the two sediment layers differed in the occurrence of large specimens ( $>450 \mu \mathrm{m}$ in length) in $0.5-1 \mathrm{~cm}$ depth which led to a significant difference between the layers $(\mathrm{K}-\mathrm{S}$ test results: $\mathrm{P}<0.05)$. On 4 August, huge numbers of juveniles occurred only in the surface sediment layer, while larger specimens dominated the A. tepida population of the $0.5-1 \mathrm{~cm}$ depth (Fig. 8 , K-S test results: $\mathrm{P}<0.001$ ).

Figure 8

\section{Discussion}

\subsection{Microdistribution of living (stained) foraminifera}

It is well known that patchiness may be an important issue, particularly in stressed, shallow systems like intertidal mudflats. The microdistribution of foraminifera may induce bias, especially on absolute abundances (see a review in Morvan, Debenay, Jorissen, Redois, Bénéteau, Delplancke et al., 2006). Most authors (e.g. Alve \& Murray, 2001; Licari, Schumacher, Wenzhöfer, Zabel \& Mackensen, 2003) made replicates when they used core sampling method. In contrast, a study on salt marsh foraminifera microhabitats by Goldstein, Watkins \& Kuhn (1995) had only a single core per sampling site. In the present study, the potential bias due to small-scale patchiness of foraminifera was tested by using two different sampling methods. The t-tests for paired data indicate that similar results were obtained with both methods. This suggests that small-scale patchiness of foraminifera does not affect 
significantly the results in the study site during the sampling period and that the collection of a single core per sampling date did not induce significant biases.

\subsection{Short-term hypoxic conditions}

From the end of May to mid-June, the geochemical characteristics at the water-sedimentinterface and within the sedimentary column underwent marked changes. A sudden decrease in Chl $a$ concentrations occurred during the second week of June. An increase in POC and PON values was found on 9 June and hypoxic conditions in the water column from 25 May to 9 June (Table 1). At the same time, high concentrations of dissolved ammonia, which is composed of un-ionised $\left(\mathrm{NH}_{3}-\mathrm{N}\right)$ and ionised forms $\left(\mathrm{NH}_{4}{ }^{+}\right)$, were recorded in the sediment porewater in the upper horizons of sediment cores. The anaerobic oxidation of organic nitrogen yielded the un-ionised form which is the most toxic to aquatic organisms (Kir, Kumlu \& Eroldogan, 2004). A decrease in microphytobenthos concentrations occurred also when the $\mathrm{NH}_{4}^{+}$concentrations were the highest. Important amounts of biodeposits, which accumulated during autumn and winter under the oyster culture tables (Lerat et al., 1985), led to organic enrichment of the sediment (Sornin et al., 1983; Ottman \& Sornin, 1985), followed by remineralisation. $\delta^{13} \mathrm{C}$ and $\delta^{15} \mathrm{~N}$ values from the top $1 \mathrm{~cm}$ of sediments also confirmed that oyster biodeposits contribute to the organic enrichment of the sediment (Feuillet-Girard, Héral, Abrioux \& Fontugne, 1994; Riera et al., 1996; Kang, Sauriau, Richard \& Blanchard, 1999). In association with the increasing temperatures during spring and early summer diurnal emersions, the remineralisation of accumulated organic matter on intertidal mudflats is accelerated (Mazouni, Gaertner, Deslous-Paoli, Landrein \& Geringer d'Oedenberg, 1996; Vouvé et al., 2000). Sediment-water exchanges were altered and short-term sediment anoxia likely occurred within surface sediments. Feuillet-Girard et al. (1988) indicated that sediment anoxia permits $\mathrm{NH}_{4}{ }^{+}$fluxes from the sediment to the water column. Santschi et al. (1990) 
reported the redox sequence commonly observed in time and space. A value of $-160 \mathrm{mV}$ is characteristically observed at $40 \mathrm{~cm}$ depth, associated with sulphate reduction. However, we observed this value at only $1 \mathrm{~cm}$ depth. Anaerobic processes occurred at very shallow depths, due to enhanced remineralisation which produced sulfide in the topmost layers on 1 June. Thus, both organic enrichment by oyster cultures and seasonal warming induced an alteration of the biochemical cycles in the sedimentary column.

\subsection{Temperature, hypoxia and ammonium: limiting factors for living foraminifera}

As seen previously, high temperatures and hypoxic waters characterised the critical period from the end of May to mid-June. This environmental disturbance strongly affected living (stained) foraminiferal assemblages through significant modifications in the density and the population structure between 25 May and 9 June, and may have contributed to the maximum of mortality for oysters that occurred from early to mid-June.

Large amounts of organic matter in the sediments and high temperatures are known to enhance foraminifera development. Lee \& Müller (1974) demonstrated that the optimal range of temperature for reproduction of coastal species is between 20 and $30^{\circ} \mathrm{C}$. The generation time of Ammonia tepida shifts from 88 days at $20^{\circ} \mathrm{C}$, to 33 days at $30^{\circ} \mathrm{C}$ (Bradshaw, 1961). In our study however, the temperature range previously found most favourable for foraminifera reproduction coincided with the period of maximal decline in foraminifera abundances. Temperatures were not high enough to explain such a mortality, which could be explained by a synergetic effect of several deleterious parameters. The combination of a general increase and diurnal pulses in temperature may boost the remineralisation of accumulated organic matter (Vouvé et al., 2000). This remineralisation consumes oxygen and may in turn lead to oxygen depletion in the ambient water and the surface sediment porewater. Thus, temperature may have a paradoxical effect on living foraminifera such that temperature enhances the 
reproduction until a critical value above which it becomes an indirectly limiting factor through its influence on biogeochemical processes.

Oxygen is a prime factor controlling and structuring benthic ecosystems, including their foraminiferal assemblages (den Dulk et al., 2000). Depending on the level of oxygenation, sensitive species of foraminifera may or may not be present. For instance, Elphidium magellanicum and Stainforthia fusiformis are oxytolerant species (Alve, 1995a; Gustafsson \& Nordberg, 2000). In this study, hypoxic conditions (20\% air-saturated water, Eh=-160 mV) occurred from 26 May and 10 June. Simultaneously, the structure of the foraminiferal assemblages was modified.

From the RFDs established for the three layers $(0-0.5,0.5-1$ and $5-8 \mathrm{~cm})$, it appeared that foraminiferal assemblages in the topmost sediments were more affected than those in the deepest which were equally dominated by two species for the entire survey period. Changes in RFDs are sensitive to events that affects dynamics of foraminiferal populations such recruitment and mortality. Large recruitment of a dominant species increases both its abundance and rank and lead to a shift in RFDs from intermediate or mature stages (curves 2 and 3) to pioneer stage (curve 1). In the uppermost slice, the living foraminiferal assemblage was at a mature stage on 22 April and five species dominated: Ammonia tepida, Brizalina striatula, Haynesina germanica, Cribroelphidium excavatum and Quinqueloculina seminula. This assemblage was subsequently altered by 9 June and species dominances were similar to those of deeper layers. At the same time, only A. tepida dominated the assemblages. The other species declined but did not disappear totally. From late June, a recovery in environmental conditions allowed regeneration and reorganisation of the living foraminiferal assemblages dominated by large recruitments of juvenile $A$. tepida. Contrary to the topmost layers, benthic foraminiferal assemblages in the $5-8 \mathrm{~cm}$ slice were not modified during the hypoxic crisis recorded in surface sediment. RFDs indicated that the assemblages were constant in shape, 
with $A$. tepida and $C$. excavatum as the dominant species, on all sampling dates. Environmental conditions in the 5-8 cm slice remained fairly similar during the study, and the same two species appeared to be tolerant of the anoxia that occurs regularly at this level.

\subsection{Haynesina germanica and Brizalina striatula (sensitive species), Ammonia tepida (tolerant species) and Cribroelphidium gunteri (pioneer species)}

Many foraminiferal species have been reported to be tolerant to oxygen depletion and organic matter enrichment. For instance, Bernhard (1993) indicated that meiofauna taxa (ostracoda, nematods and copepods) totally disappear during anoxia whereas living foraminifera were tolerant to short periods of anoxia and sulfide fluxes. The living benthic foraminiferal assemblages described in our study illustrate their resistant capacity, e.g. Ammonia tepida dominated the stained assemblage during the whole sampling period with an average occurrence of $80 \%$. Samir (2000), in his study on the foraminiferal assemblages of the Nile delta, also reported $A$. tepida as the most tolerant species in environments submitted to organic pulses. Armynot du Châtelet, Debenay \& Soulard (2004) reported the same characteristic for A. tepida in their study on foraminiferal assemblages in moderately polluted harbours. Moreover, although its abundances declined, A. tepida was able to regenerate rapidly as a recruitment of juveniles occurred in August, characterised by individuals with three chambers or fewer.

The abundances of Haynesina germanica and Brizalina striatula, however decreased significantly and rapidly during the hypoxia event. They appeared to be sensitive to organic degradation and anoxia, in contrast to Armynot du Châtelet et al. (2004) and Debenay, Millet \& Angelidis (2005) description of $H$. germanica as tolerant to organic matter enrichment. Thus, both hypoxia and high ammonia concentrations may be the main variables explaining the decline of $H$. germanica. Observations of living foraminiferal assemblages on 4 August, 
showed that the abundance of Cribroelphidium gunteri had increased significantly whereas the abundances of the other species were still low and $C$. gunteri had became the dominant species together with A. tepida. Debenay et al. (2006) reported C. gunteri as a pioneer species. Moreover, Boudreau, Patterson, Dalby \& McKillop (2001) reported this species to occur in fresh waters showing its great adaptability to various environmental conditions. In their study, they observed a rapid development of $C$. gunteri, and concluded that it is a pioneer species. $C$. gunteri appears better specialised for colonisation and dispersal than the other species in this study.

\section{Conclusion}

The remineralisation of the organic matter that had accumulated under the oyster racks was controlled by the seasonal warming. This occurred in conjunction with an hypoxic crisis in the water column at the beginning of the warmest season. We have found that living (stained) foraminiferal assemblages in the topmost layer were significantly altered during this warmseason hypoxic event, and that living (stained) foraminiferal responses were species specific. Haynesina germanica and Brizalina striatula are sensitive to hypoxia and ammonia concentration and changes in their abundance may be considered as good proxies for such events. However, sensitive species did not totally disappear. Ammonia tepida appears as a tolerant species capable of regenerating its abundances rapidly and Cribroelphidium gunteri appears as a pioneer species able to rapidly colonize the topmost sediment layers after the warm-season hypoxic event. These results from living (stained) foraminiferal dynamics and assemblage structures finally support the idea that toxic changes in sediment biochemistry are involved in Pacific oyster summer mortalities.

\section{Acknowledgements}


The authors are grateful to F. Blouin ${ }^{\dagger}$, P. Malestroit, J.-L. Seugnet, L. Joassard and M. Bréret for their assistance during field and laboratory work. This study was supported by CNRS and IFREMER through the program on summer mortality of Pacific oysters "MOREST" conducted by J.-F. Samain. This study also received support from the Région PoitouCharente. V.B. was supported by a $\mathrm{PhD}$ grant from Angers Agglomération. The paper benefited from the helpful comments of David B. Scott, Hugh Grenfell, Peter Frenzel, two anonymous referees and the editor J. Widdows. 


\section{References}

Alve, E. (1995a). Benthic foraminiferal distribution and recolonization of formerly anoxic environments in Drammensfjord, southern Norway. Marine Micropaleontology, 25, 169-186.

Alve, E. (1995b). Benthic foraminiferal responses to estuarine pollution: a review. Journal of Foraminiferal Research, 25, 190-203.

Alve, E. (2003). A common opportunistic foraminiferal species as an indicator of rapidly changing conditions in a range of environments. Estuarine, Coastal and Shelf Science, $57,501-514$.

Alve, E., \& Murray, J.W. (2001). Temporal variability in vertical distributions of live (stained) intertidal foraminifera, southern England. Journal of Foraminiferal Research, $31,12-24$.

Angel, D.L., Verghese, S., Lee, J.J., Saleh, A.M., Zuber, D., Lindell, D., \& Symons, A. (2000). Impact of a net cage fish farm on the distribution of benthic foraminifera in the northern Gulf of Eilat (Aqaba, Red Sea). Journal of Foraminiferal Research, 30, 5465.

Annin, V.K. (2001). Benthic foraminifera assemblages as bottom environmental indicators, Posiet Bay, Sea of Japan. Journal of Asian Earth Sciences, 20, 9-29.

Armynot du Châtelet, E., Debenay, J.-P., \& Soulard, R. (2004). Foraminiferal proxies for pollution monitoring in moderately polluted harbors. Environmental Pollution, 127, $27-40$

Bernhard, J.M. (1993). Experimental and field evidence of Antartic foraminiferal tolerance to anoxia and hydrogen sulfide. Marine Micropaleontology, 20, 203-214. 
Boudreau, R.E.A., Patterson, T.R., Dalby, A.P., \& McKillop, W.B. (2001). Non-marine occurrence of the foraminifer Cribroelphidium gunteri in northern Lake Winnipegosis, Manitoba, Canada. Journal of Foraminiferal Research, 31, 108-119.

Bradshaw, J.S. (1961). Laboratory experiments on the ecology of foraminifera. Contributions from the Cushman Foundation for Foraminiferal Research, 12, 87-106.

Castel, J., Labourg, P.-J., Escaravage, V., Auby, I., \& Garcia, M.E. (1989). Influence of seagrass beds and oyster parks on the abundance and biomass patterns of meio- and macrobenthos in tidal flats. Estuarine, Coastal and Shelf Science, 28, 71-85.

Cheney, D.P., MacDonald, B.F., \& Elston, R.A. (2000). Summer mortality of Pacific oysters, Crassostrea gigas (Thunberg): initial findings on multiple environmental stressors in Puget Sound, Washington. Journal of Shellfish Research, 19, 353-359.

Christensen, P.B., Glud, R.N., Dalsgaard, T., \& Gillespie, P. (2003). Impacts of longline mussel farming on oxygen and nitrogen dynamics and biological communities of coastal sediments. Aquaculture, 218, 567-588.

Cline, J.D. (1969). Determination of hydrogen sulfide in natural waters. Limnology and Oceanography, 14, 454-458.

Costil, K., Royer, J., Ropert, M., Soletchnik, P., \& Mathieu, M. (2005). Spatio-temporal variations in biological performances and summer mortality of the Pacific oyster Crassostrea gigas in Normandy. Helgoland Marine Research, 59, 286-300.

Davoult, D., Dewarumez, J.-M., \& Migné, A. (1998). Long-term changes (1979-1994) in two coastal benthic communities (English Channel): analysis of structural developments. Oceanologica Acta, 21, 609-617.

De Rijk, S., Jorissen, F.J., Rohling, E.J., \& Troelstra, S.R. (2000). Organic flux control on bathymetric zonation of Mediterranean benthic foraminifera. Marine Micropaleontology, 40, 151-166. 
Debenay, J.-P., Bicchi, E., Goubert, E., \& Armynot du Châtelet, E. (2006). Spatio-temporal distribution of benthic foraminifera in relation to estuarine dynamics (Vie estuary, Vendée, W France). Estuarine, Coastal and Shelf Science, 67, 181-197.

Debenay, J.-P., Millet, B., \& Angelidis, M.O. (2005). Relationships between foraminiferal assemblages and hydrodynamics in the Gulf of Kalloni, Greece. Journal of Foraminiferal Research, 35, 327-343.

Debenay, J.-P., Tsakiridis, E., Soulard, R., \& Grossel, H. (2001). Factors determining the distribution of foraminiferal assemblages in Port Joinville Harbor (Ile d'Yeu, France): the influence of pollution. Marine Micropaleontology, 43, 75-118.

Dégremont, L., Bedier, E., Soletchnik, P., Ropert, M., Huvet, A., Moal, J., Samain, J.-F., \& Boudry, P. (2005). Relative importance of family, site, and field placement timing on survival, growth, and yield of hatchery-produced Pacific oyster spat (Crassostrea gigas). Aquaculture, 249, 213-229.

den Dulk, M., Reichart, G.J., van Heyst, S., Zachariasse, W.J., \& van der Zwaan, G.J. (2000). Benthic foraminifera as proxies of organic matter flux and bottom water oxygenation? A case history from the northern Arabian Sea. Palaeogeography, Palaeoclimatology, Palaeoecology, 161, 337-359.

Deslous-Paoli, J.-M., Souchu, P., Mazouni, N., Juge, C., \& Dagault, F. (1998). Relations milieu-ressources : impact de la conchyliculture sur un environnement lagunaire méditerranéen (Thau). Oceanologica Acta, 21, 831-843.

Dinet, A., Sornin, J.-M., Sablière, A., Delmas, D., \& Feuillet-Girard, M. (1990). Influence de la biodéposition de bivalves filtreurs sur les peuplements méiobenthiques d'un marais maritime. Cahiers de Biologie Marine, 31, 307-322. 
Ernst, S., Bours, R., Duijnstee, I., \& van der Zwaan, B. (2005). Experimental effects of an organic matter pulse and oxygen depletion on a benthic foraminiferal shelf community. Journal of Foraminiferal Research, 35, 177-197.

Fatela, F., \& Taborda, R. (2002). Confidence limits of species proportions in microfossils assemblages. Marine Micropaleontology, 45, 169-174.

Feuillet-Girard, M., Héral, M., Abrioux, M.-F., \& Fontugne, M. (1994). Carbone organique dissous et particulaire de la colonne d'eau et de l'interface eau-sédiment du bassin de Marennes-Oléron : influence des huîtres. Oceanologica Acta, 17, 271-284.

Feuillet-Girard, M., Héral, M., Sornin, J.-M., Deslous-Paoli, J.-M., Robert, J.-M., Mornet, F., \& Razet, D. (1988). Eléments azotés de la colonne d'eau et de l'interface eau-sédiment du bassin de Marennes-Oléron : influence des cultures d'huîtres. Aquatic Living Resources, 1, 251-265.

Frontier, S. (1985). Diversity and structure in aquatic ecosystems. Oceanography and Marine Biology. An Annual Review, 23, 253-312.

Gagnaire, B., Soletchnik, P., Madec, P., Geairon, P., Le Moine, O., \& Renault, T. (2006). Diploid and triploid Pacific oysters, Crassostrea gigas (Thunberg), reared at two heights above sediment in Marennes-Oleron Basin, France: difference in mortality, sexual maturation and hemocyte parameters. Aquaculture, 254, 606-616.

Glude, J.B. (1974). A summary report of Pacific Coast oyster mortality investigations 19651972, October 15-16th 1974. Proceedings of the Third U.S.-Japan meeting on Aquaculture, Tokyo.

Goldstein, S.T., Watkins, G.T., \& Kuhn, R.M. (1995). Microhabitats of salt marsh foraminifera: St. Catherines Island, Georgia, USA. Marine Micropaleontology, 26, 1729. 
Grant, J., Hatcher, A., Scott, D.B., Pocklington, P., Schafer, C.T., \& Winters, G.V. (1995). A multidisciplinary approach to evaluating impacts of shellfish aquaculture on benthic communities. Estuaries, 18, 124-144.

Gray, J.S., Wu, R.S.S., \& Or, Y.Y. (2002). Effects of hypoxia and organic enrichment on the coastal marine environment. Marine Ecology Progress Series, 238, 249-279.

Gustafsson, M., \& Nordberg, K. (2000). Living (stained) benthic foraminifera and their response to the seasonal hydrographic cycle, periodic hypoxia and to primary production in Havstens Fjord on the Swedish west coast. Estuarine, Coastal and Shelf Science, 51, 743-761.

Hartstein, N.D., \& Rowden, A.A. (2004). Effect of biodeposits from mussel culture on macroinvertebrate assemblages at sites of different hydrodynamic regime. Marine Environmental Research, 57, 339-357.

Hily, C. (1983). Dynamique de la recolonisation par la macrofaune d'un substrat dragué à proximité du port de Brest. Oceanologica Acta, 15, 113-120.

Holm-Hansen, O., Lorenzen, C.J., Holmes, R.W., \& Strickland, J.D.H. (1965). Fluorometric determination of chlorophyll. Journal du Conseil permanent international pour l'Exploration de la Mer, 30, 3-15.

Hurbert, S.J. (1984). Pseudoreplication and the design of ecological experiments. Ecological Monographs, 54, 187-211.

Imaï, T., Numachi, J., Oizumi, J., \& Sato, S. (1965). Studies on the mass mortality of the oyster in Matsushima Bay. II. Search for the cause of mass mortality and possibility to prevent it by transplantation experiment. Bulletin Tohoku Regional Fisheries Research Labories, 25, 27-38.

Kang, C.K., Sauriau, P.G., Richard, P., \& Blanchard, G.F. (1999). Food sources of the infaunal suspension-feeding bivalve Cerastoderma edule in a muddy sandflat of 
Marennes-Oléron Bay, as determined by analyses of carbon and nitrogen stable isotopes. Marine Ecology Progress Series, 187, 147-158.

Kir, M., Kumlu, M., \& Eroldogan, O.T. (2004). Effects of temperature on acute toxicity of ammonia to Penaeus semisulcatus juveniles. Aquaculture, 241, 479-489.

Le Calvez, J., \& Le Calvez, Y. (1958). Répartition des foraminifères dans la baie de Villefranche. 1-Miliolidae. Annales de l'Institut Océanographique Monaco, 35, 159234.

Lee, J.J., \& Müller, W.A. (1974). Trophic dynamics and niches of salt marsh foraminifera. Annales Zoologici, 13, 215-223.

Legendre, L., \& Legendre, P. (1984). Ecologie numérique. 2nd édition 1. Le traitement multiple des données écologiques. Paris \& Québec: Masson \& les Presses de l'Université du Québec.

Lerat, Y., Boucher, G., \& Le Corre, P. (1985). Echanges à l'interface eau-sédiment dans un secteur côtier à forte biodéposition (parc ostréicole), cas de l'ammonium et des nitrates. Cahiers de Biologie Marine, 26, 393-408.

Licari, L.N., Schumacher, S., Wenzhöfer, F., Zabel, M., \& Mackensen, A. (2003). Communities and microhabitats of living benthic foraminifera from the tropical East Atlantic: impact of different productivity regimes. Journal of Foraminiferal Research, $33,10-31$.

Loeblich Jr., A.R., \& Tappan, H. (1988). Foraminiferal genera and their classification. New York: Van Nostrand Reinhold Company.

Mallet, A.L., Carver, C.E., \& Landry, T. (2006). Impact of suspended and off-bottom Eastern oyster culture on the benthic environment in eastern Canada. Aquaculture, 255, 362373. 
Maurer, D., Comps, M., \& His, E. (1986). Caractéristiques des mortalités printanières de l'huître Crassostrea gigas dans le bassin d'Arcachon. Haliotis, 15, 309-317.

Mazouni, N., Gaertner, J.-C., Deslous-Paoli, J.-M., Landrein, S., \& Geringer d'Oedenberg, M. (1996). Nutrient and oxygen exchanges at the water-sediment interface in a shellfish farming lagoon (Thau, France). Journal of Experimental Marine Biology and Ecology, 205, 91-113.

Morvan, J., Debenay, J.-P., Jorissen, F., Redois, F., Bénéteau, E., Delplancke, M., \& Amato, A.-S. (2006). Patchiness and life cycle of intertidal foraminifera: implication for environmental and paleoenvironmental interpretation. Marine Micropaleontology, 61, 131-154.

Morvan, J., Le Cadre, V., Jorissen, F., \& Debenay, J.-P. (2004). Foraminifera as potential bioindicators of the "Erika" oil spill in the Bay of Bourgneuf: field and experimental studies. Aquatic Living Resources, 17, 317-322.

Mouillot, D., \& Lepretre, A. (2000). Introduction of relative abundance distribution (RAD) indices, estimated from the rank-frequency diagrams (RFD), to access changes in community diversity. Environmental Monitoring and Assessment, 63, 279-295.

Murray, J.W. (2000). The enigma of the continued use of total assemblages in ecological studies of benthic foraminifera. Journal of Foraminiferal Research, 30, 244-245.

Murray, J.W., \& Bowser, S.S. (2000). Mortality, protoplasm decay rate, and reliability of staining techniques to recognize 'living' foraminifera: a review. Journal of Foraminiferal Research, 30, 66-70.

Nugues, M.M., Kaiser, M.J., Spencer, B.E., \& Edwards, D.B. (1996). Benthic community changes associated with intertidal oyster cultivation. Aquaculture Research, 27, 913924. 
Ottman, F., \& Sornin, J.M. (1985). Observations on sediment accumulation as a result of mollusk culture systems in France. Proceedings of the international symposium on utilization of coastal ecosystem: planning, pollution and productivity, Rio Grande, Brasil.

Ragnarsson, S.A., \& Raffaelli, D. (1999). Effects of the mussel Mytilus edulis L. on the invertebrate fauna of sediments. Journal of Experimental Marine Biology and Ecology, 241, 31-43.

Riera, P., Richard, P., Grémare, A., \& Blanchard, G. (1996). Food source of intertidal nematodes in the Bay of Marennes-Oléron (France), as determined by dual stable isotope analysis. Marine Ecology Progress Series, 142, 303-309.

Samir, A.M. (2000). The response of benthic foraminifera and ostracods to various pollution sources: a study from two lagoons in Egypt. Journal of Foraminiferal Research, 30, 83-98.

Santschi, P., Höhener, P., Benoit, G., \& Buchholtz-ten Brink, M. (1990). Chemical processes at the sediment-water interface. Marine Chemistry, 30, 269-315.

Schafer, C.T., Winters, G.V., Scott, D.B., Pocklington, P., Cole, F.E., \& Honig, C. (1995). Survey of living foraminifera and polychaete populations at some Canadian aquaculture sites: potential for impact mapping and monitoring. Journal of Foraminiferal Research, 25, 236-259.

Scott, D.B., Schafer, C.T., Honig, C., \& Younger, D.C. (1995). Temporal variations of benthic foraminiferal assemblages under or near aquacultutre operations: documentation of impact history. Journal of Foraminiferal Research, 25, 224-235.

Seeberg-Elverfeldt, J., Schlüter, M., Feseker, T., \& Kölling, M. (2005). Rhizon sampling of porewaters near the sediment-water interface of aquatic systems. Limnology and Oceanography: Methods, 3, 361-371. 
Smith, P.B. (1963). Quantitative and qualitative analysis of the family Bolivinidae. Geological Survey Professional Paper, 39.

Soletchnik, P., Lambert, C., \& Costil, K. (2005). Summer mortality of Crassostrea gigas (Thunberg) in relation to environmental rearing conditions. Journal of Shellfish Research, 24, 197-207.

Soletchnik, P., Le Moine, O., Faury, N., Razet, D., Geairon, P., \& Goulletquer, P. (1999). Mortalité de l'huître Crassostrea gigas dans le bassin de Marennes-Oléron : étude de la variabilité spatiale de son environnement et de sa biologie par un système d'informations géographiques (SIG). Aquatic Living Resources, 12, 131-143.

Solorzano, L. (1969). Determination of ammonia in natural waters by the phenolhypochlorite method. Limnology and Oceanography, 14, 799-801.

Sornin, J.M., Feuillet, M., Héral, M., \& Deslous-Paoli, J.M. (1983). Effet des biodépôts de l'huître Crassostrea gigas (Thunberg) sur l'accumulation de matières organiques dans les parcs du bassin de Marennes-Oléron. Journal of Molluscan Studies, Suppt. 12A, 185-197.

van der Zwaan, G.J., Duijnstee, I.A.P., den Dulk, M., Ernst, S.R., Jannink, N.T., \& Kouwenhoven, T.J. (1999). Benthic foraminifers: proxies or problems? a review of paleocological concepts. Earth-Science Reviews, 46, 213-236.

Vouvé, F., Guiraud, G., Marol, C., Girard, M., Richard, P., \& Laima, M.J.C. (2000). $\mathrm{NH}_{4}^{+}$ turnover in intertidal sediments of Marennes-Oléron Bay (France): effect of sediment temperature. Oceanologica Acta, 23, 575-584.

Yentsch, C.S., \& Menzel, D.W. (1963). A method for the determination of phytoplankton chlorophyll and phaeophytin by fluorescence. Deep Sea Research, 10, 221-231.

Zar, J.H. (1984). Biostatistical analysis. Englewood Cliffs: Prentice-Hall International Editions. 


\section{Figure legends}

Figure 1. Map of the Marennes-Oléron Bay with the location of the Ronce-Perquis sampling site

Figure 2. Time series of turbidity (grey line) and oxygen content as \% air-saturation (black line) in the water column at $15 \mathrm{~cm}$ above the sediment surface at the oyster culture site of Ronce-Perquis from 22 April to 23 June.

Figure 3. Temperature time series at the sediment-water interface (grey line) and $15 \mathrm{~cm}$ sediment depth (black line) at the oyster culture site of Ronce-Perquis from 22 April to 4 August. Day-to-day changes in the tidal coefficient (see text for definition, dashed line) are shown together with mortality rate $\left(\%\right.$ day $^{-1}$; scale X 10$)$ of oysters from "onbottom" (filled circle) and "off-bottom" (open square) culture conditions.

Figure 4. Temporal changes in depth profiles of porewater ammonium and sulfide contents $\left(\mathrm{mg} \mathrm{l}^{-1}\right)$ within sediment cores sampled at Ronce-Perquis from 22 April to 4 August.

Figure 5. Changes in species richness and abundances of living (stained) foraminifera with depth of sediment cores sampled at Ronce-Perquis from 22 April to 4 August.

Figure 6. Abundances of Ammonia tepida (a), Brizalina striatula (b), Cribroelphidium excavatum (c), Cribroelphidium gunteri (d), Haynesina germanica (e) and Quinqueloculina seminula (f) at 0-0.5 (white) and 0.5-1 cm depth (grey) of sediment cores sampled at Ronce-Perquis from 22 April to 4 August.

Figure 7. Benthic foraminifera rank-frequency diagrams at $0-0.5$ (a), $0.5-1$ (b) and $5-8 \mathrm{~cm}$ depth (c) of sediment cores sampled at Ronce-Perquis from 22 April to 4 August and theoretical RFD curve shapes $(\mathrm{d}, 1:$ linear-concave $=$ pioneer assemblage, 2 : convex $=$ intermediate assemblage and 3: straight-line $=$ mature assemblage, dotted arrow $=$ example of ecological succession: recovery in the assemblage). 
Figure 8. Changes in Ammonia tepida size class frequencies at 0-0.5 (a) and 0.5-1 cm depth (b) of sediment cores sampled at Ronce-Perquis from 22 April to 4 August and $\mathrm{P}$ values are statistics for K-S test. 
Figure 1

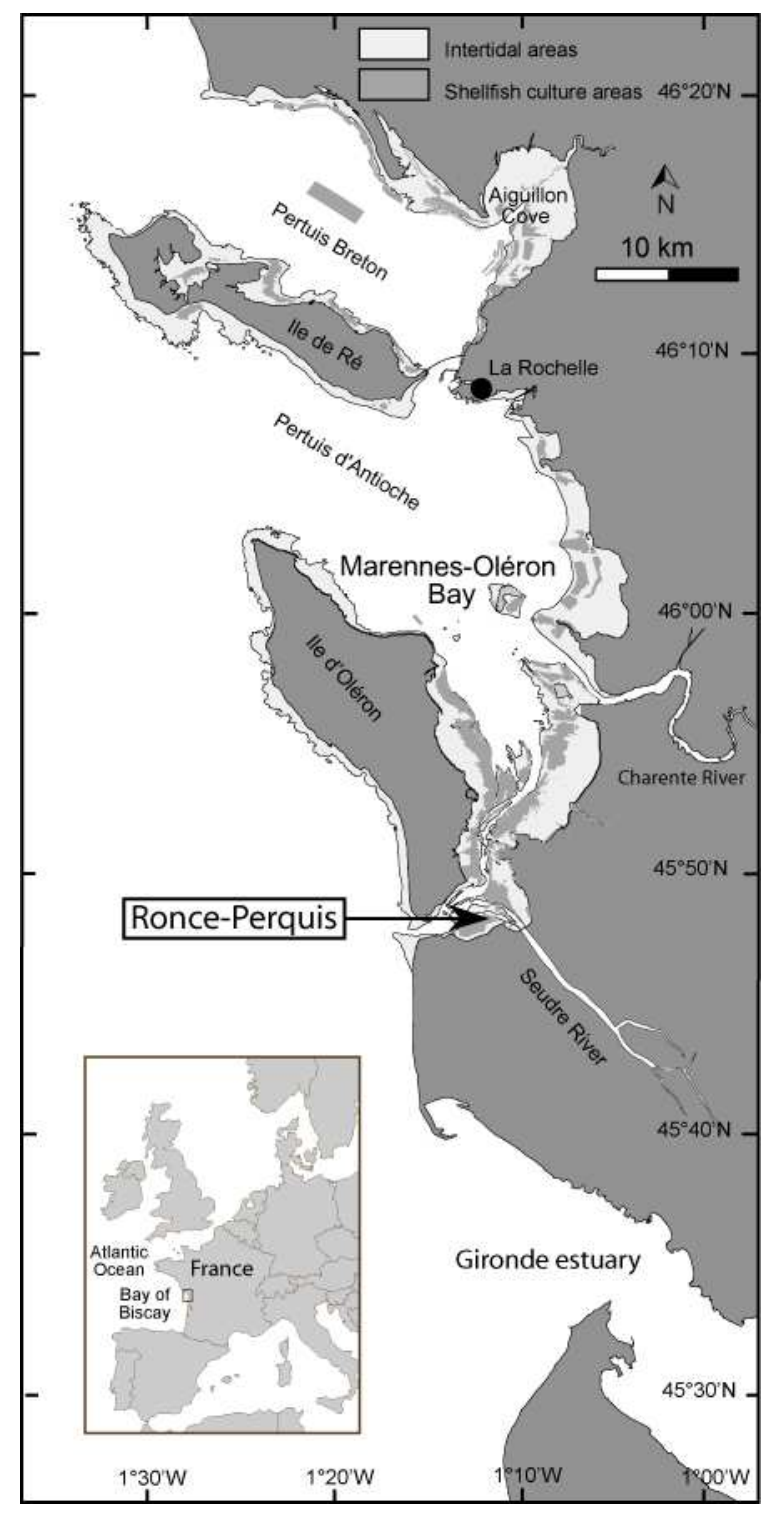


Figure 2

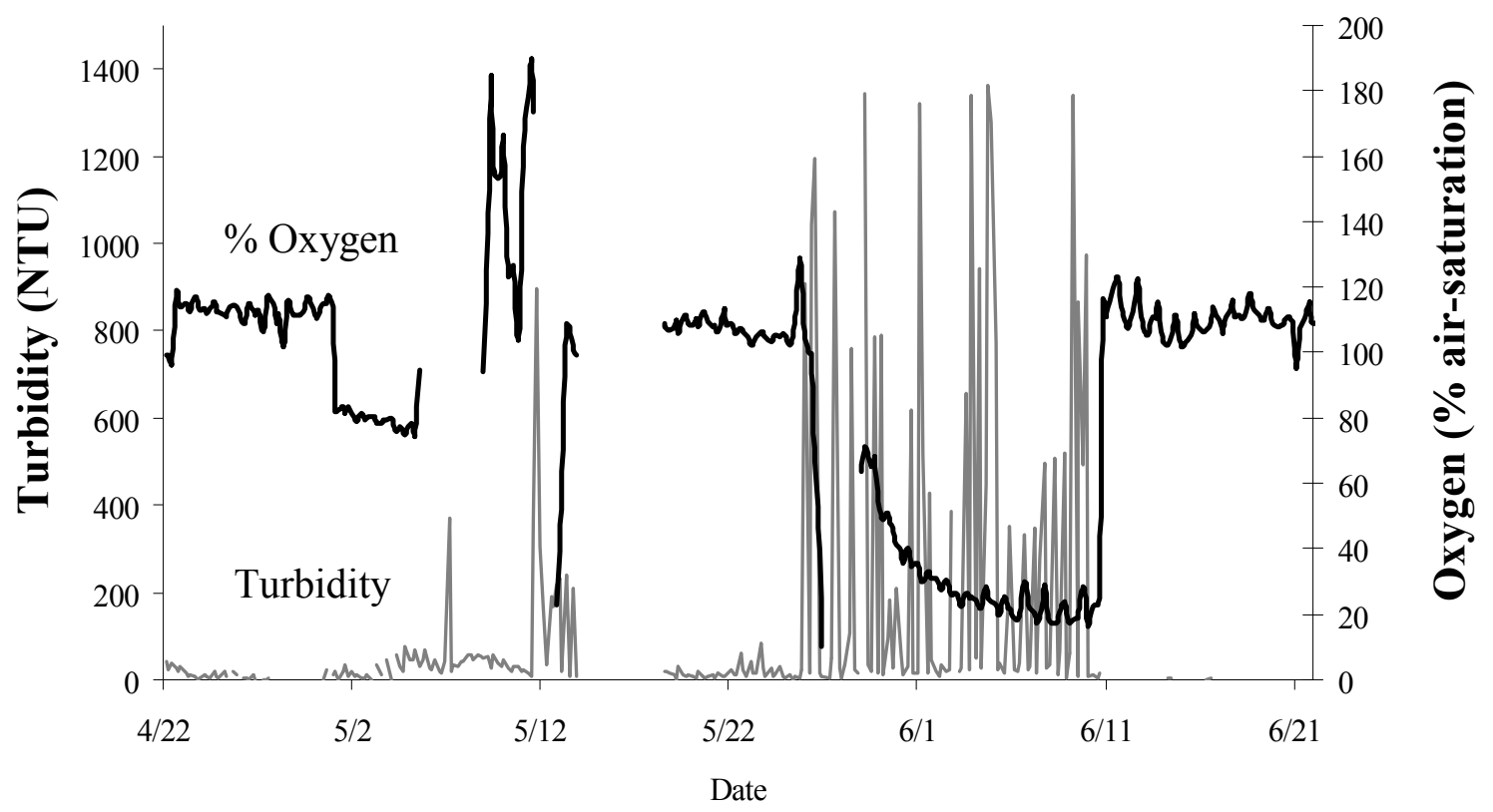


Figure 3

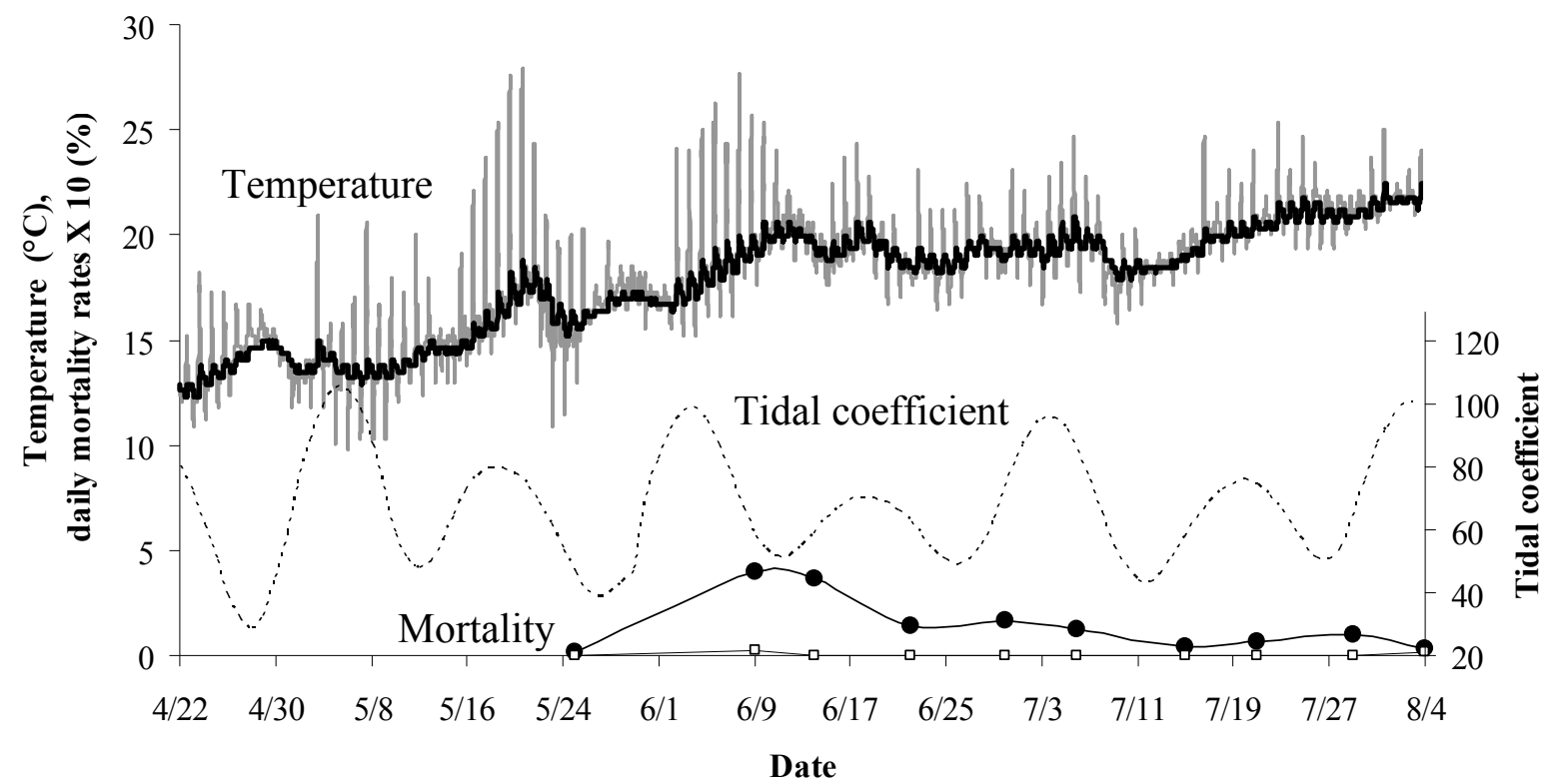


Figure 4
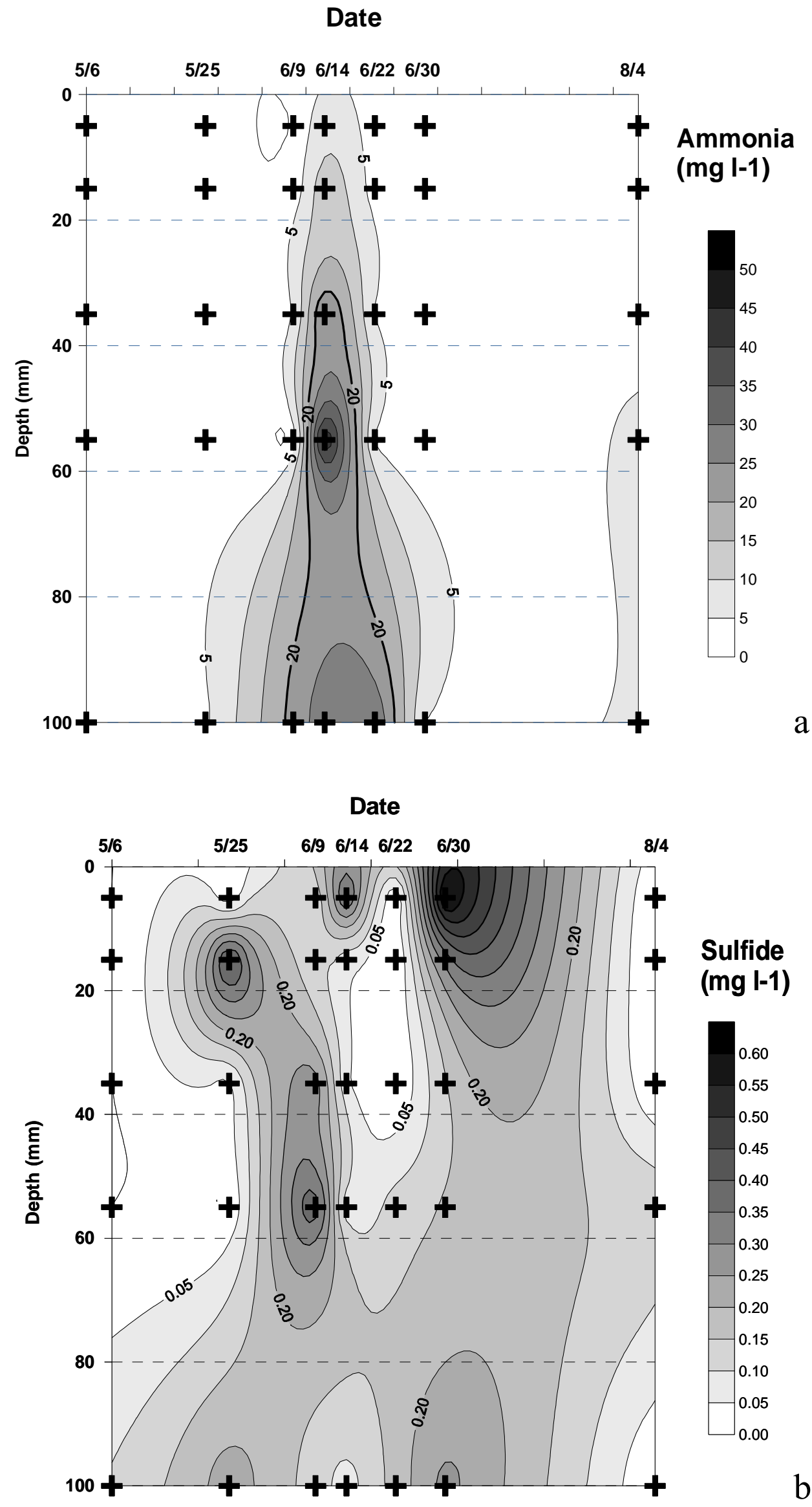
Figure 5

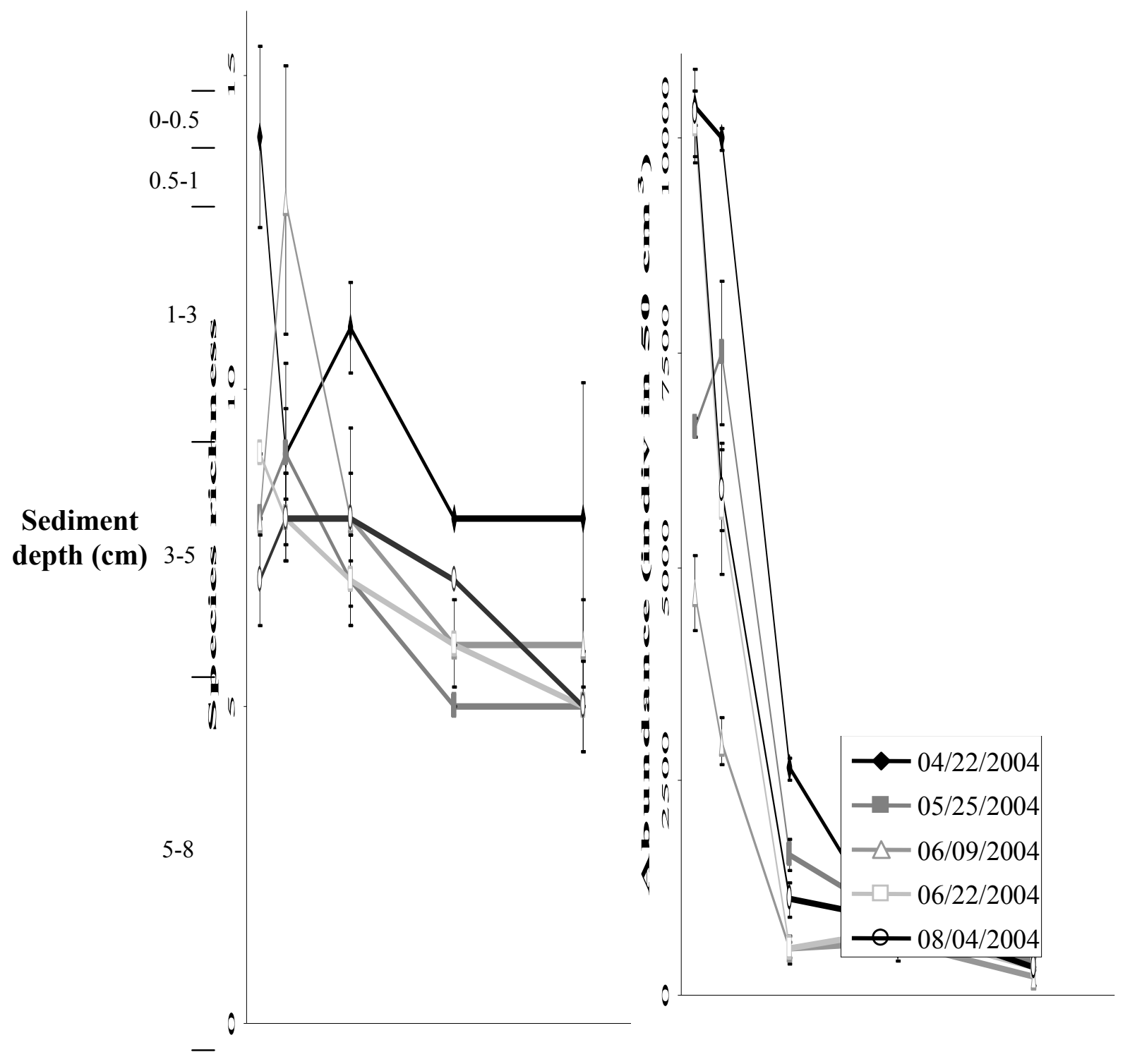


Figure 6
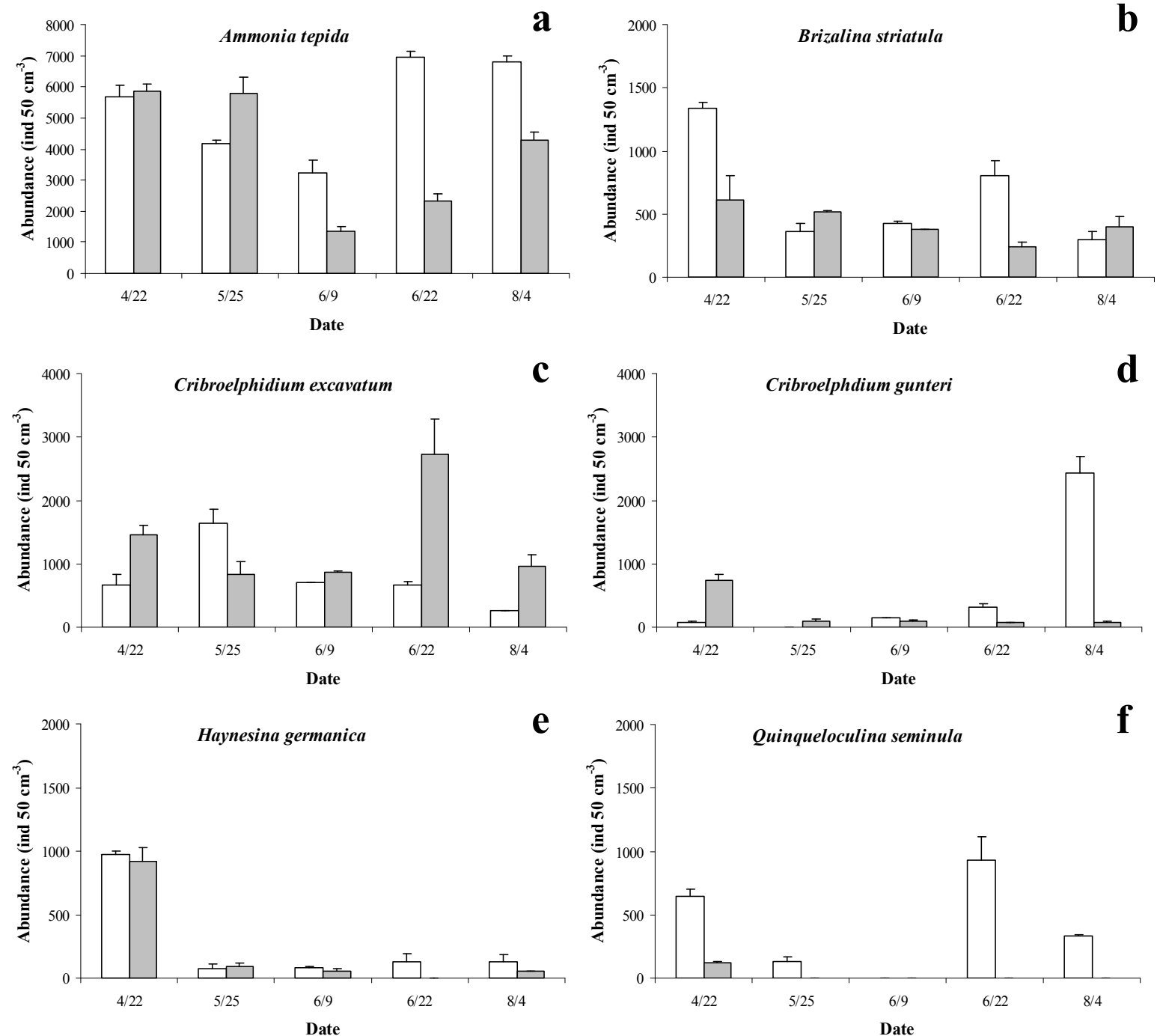
Figure 7

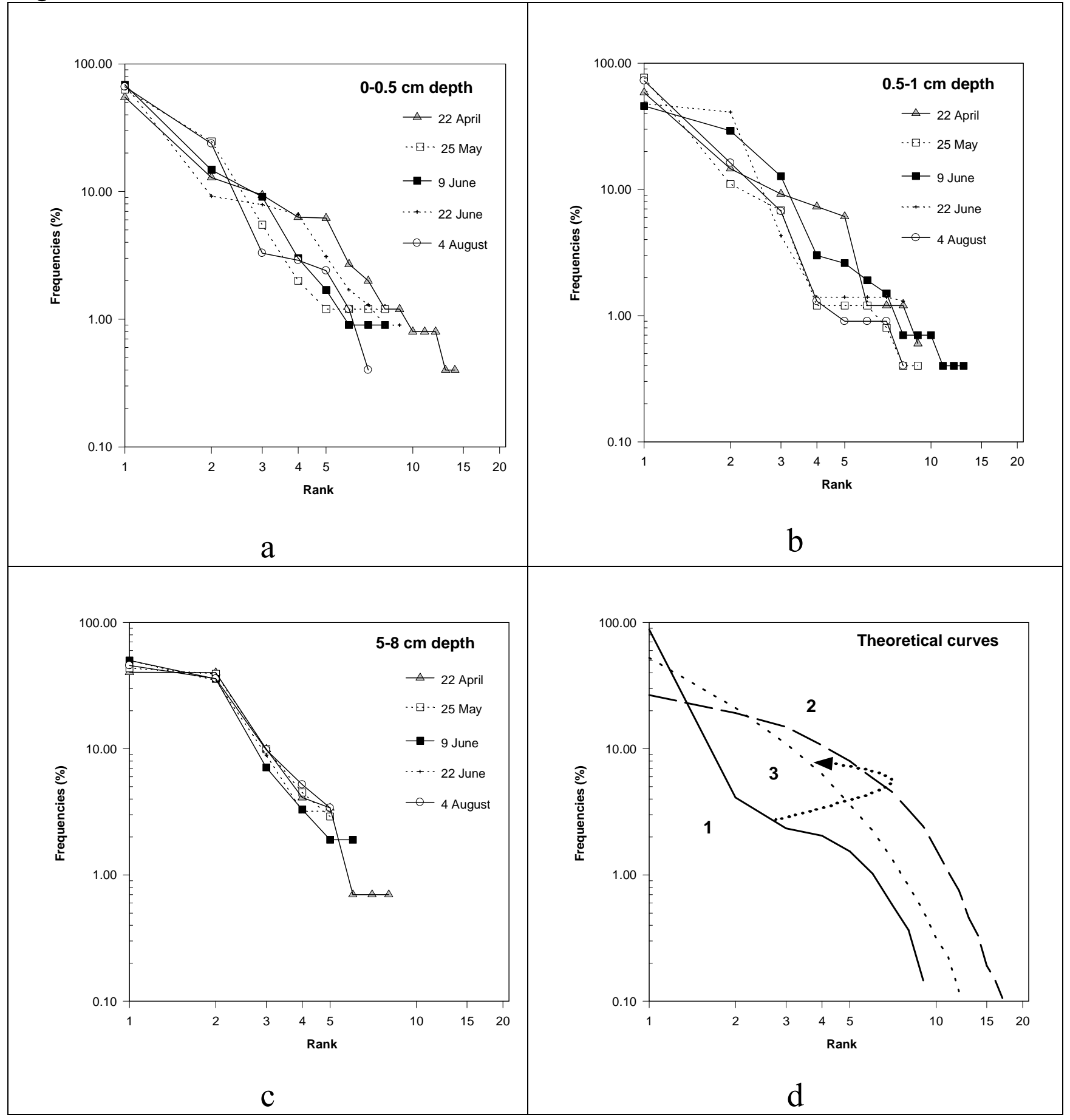


Figure 8

$0-0.5 \mathrm{~cm}$ depth (a)

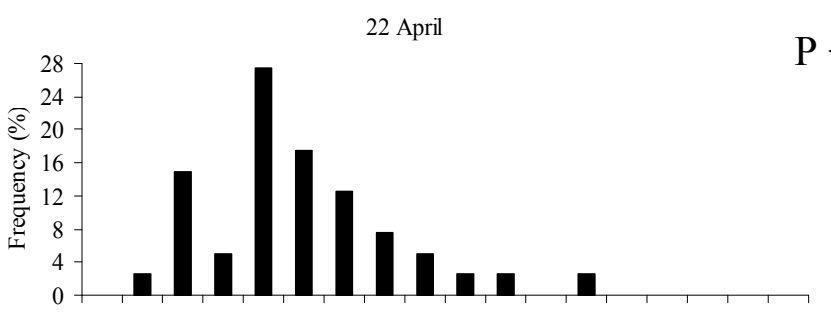

150175200225250275300325350375400425450475500525550575 Shell length $(\mu \mathrm{m})$
0.5-1 cm depth (b)

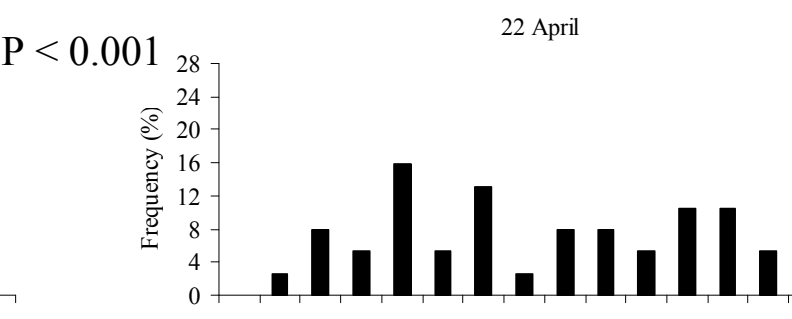

150175200225250275300325350375400425450475500525550575 Shell length $(\mu \mathrm{m})$

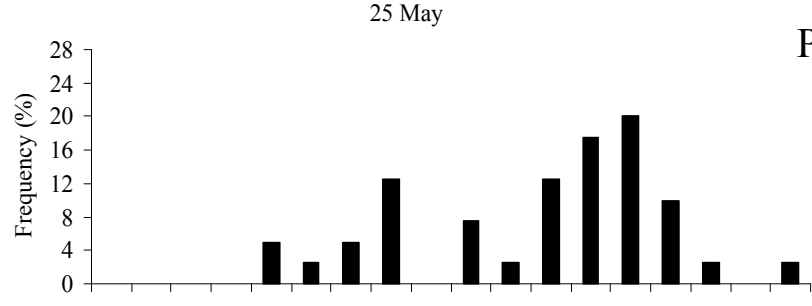

150175200225250275300325350375400425450475500525550575 Shell length $(\mu \mathrm{m})$

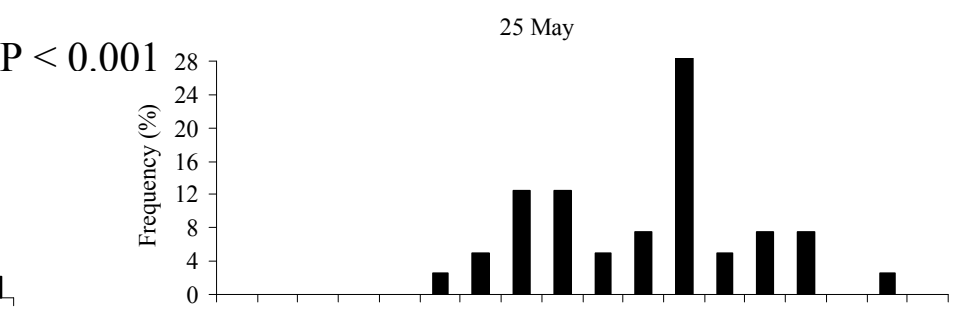

150175200225250275300325350375400425450475500525550575 Shell length $(\mu \mathrm{m})$

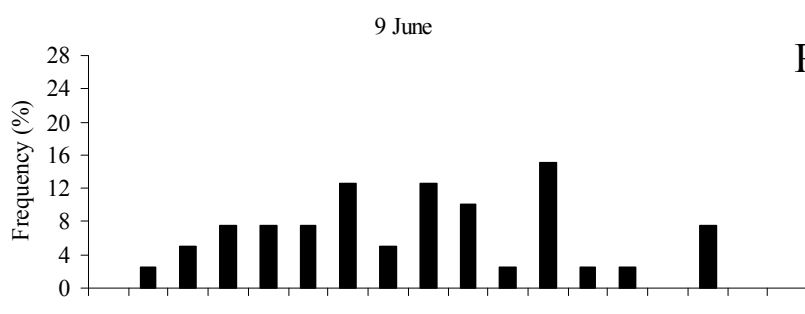

150175200225250275300325350375400425450475500525550575 Shell length $(\mu \mathrm{m})$

22 June

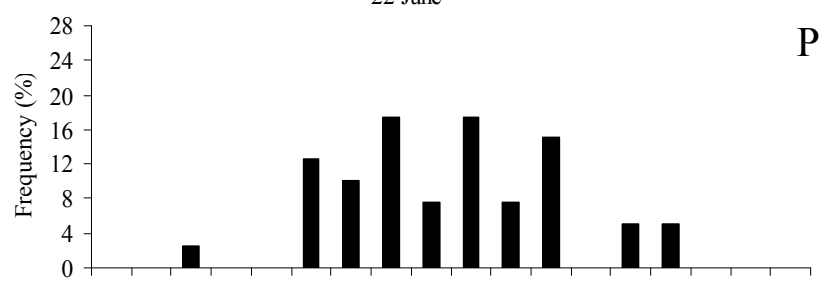

150175200225250275300325350375400425450475500525550575 Shell length $(\mu \mathrm{m})$

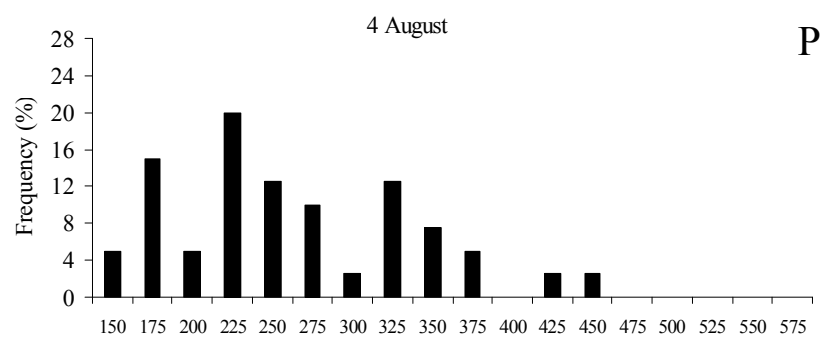
Shell length $(\mu \mathrm{m})$

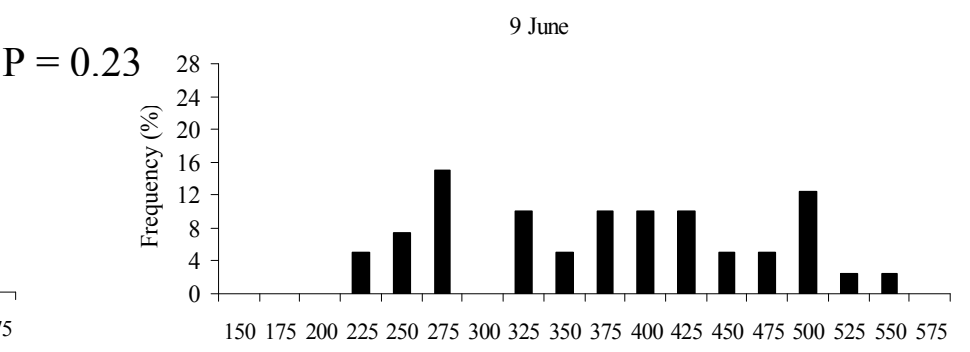

Shell length $(\mu \mathrm{m})$

22 June

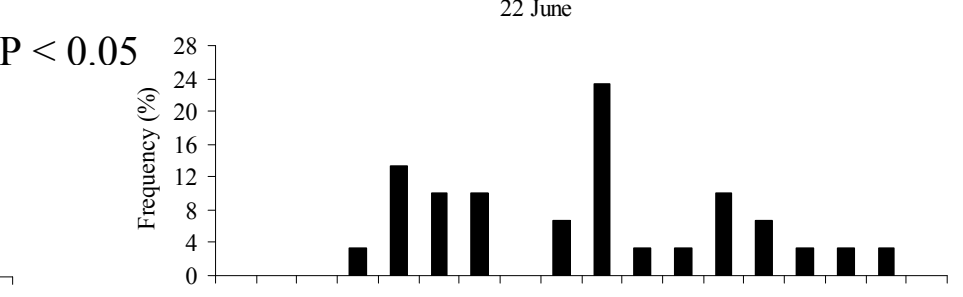

150175200225250275300325350375400425450475500525550575 Shell length $(\mu \mathrm{m})$

4 August

$\mathbf{P}<0.001$

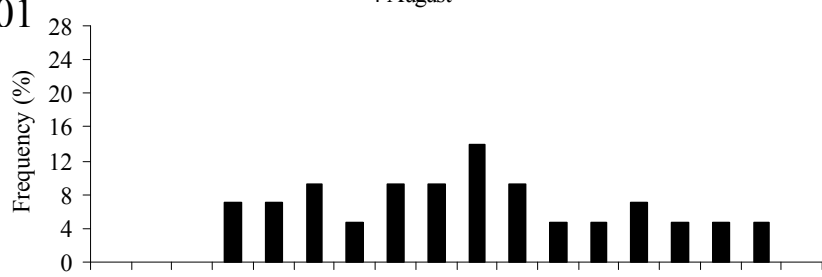

150175200225250275300325350375400425450475500525550575 Shell length $(\mu \mathrm{m})$ 
Table 1. Changes in water salinity and in sediment parameters from 22 April to 4 August 2004 (nd: no data).

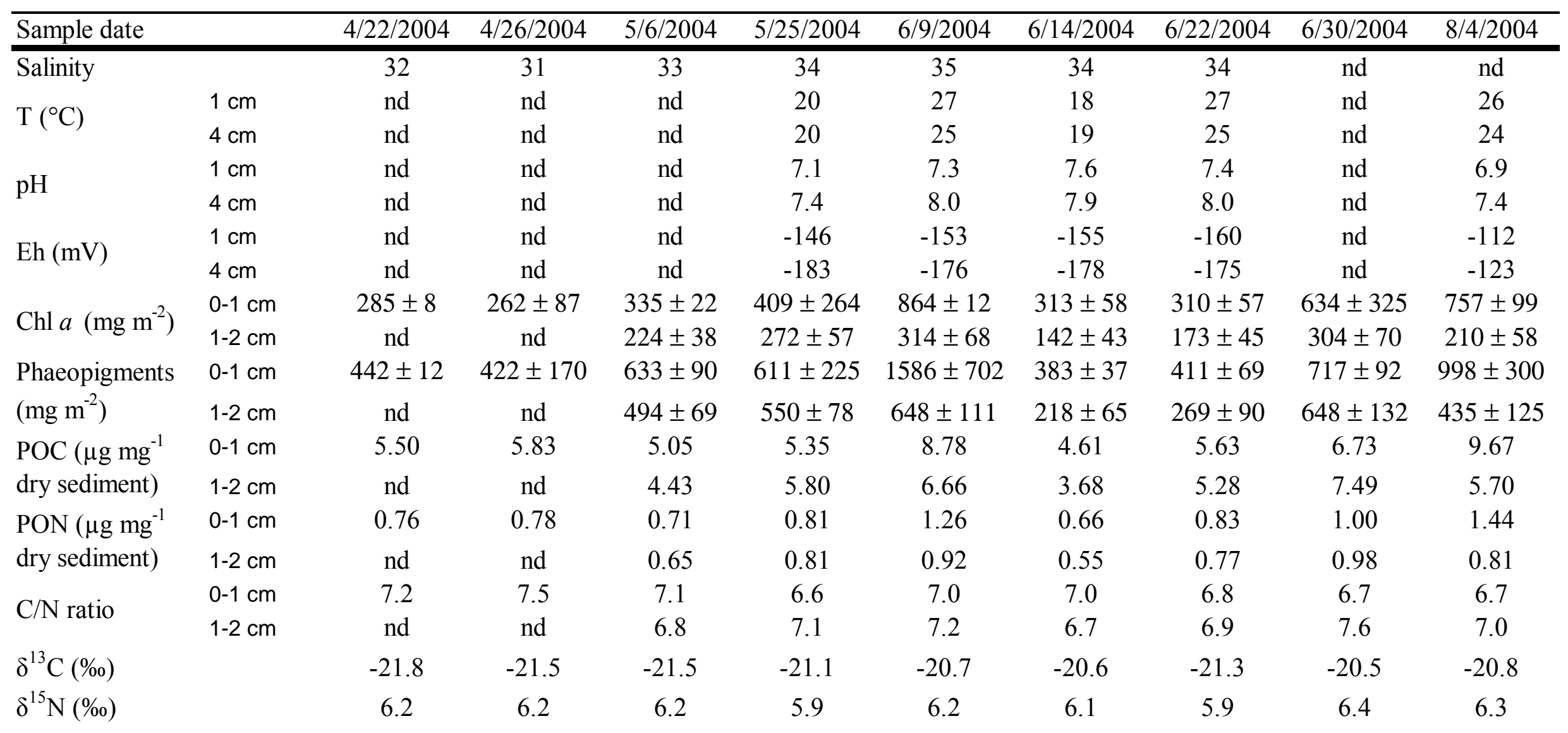


Table 2. Characteristics of the six main living (stained) species from the pseudoreplication samples (PS) and from the core samples (CS) from 0-

$0.5 \mathrm{~cm}$ sediments. Total number of living test (abundance), species richness and abundances of each species per sample from 22 April to 4

August 2004 in $50 \mathrm{~cm}^{3}$ of sediment and $\mathrm{P}$ values are statistics for Student t-test for paired data.

\begin{tabular}{lrrrrrrrrrrr}
\hline Sample date & \multicolumn{1}{c}{$04 / 22 / 2004$} & \multicolumn{2}{c}{$05 / 25 / 2004$} & \multicolumn{2}{c}{$06 / 09 / 2004$} & \multicolumn{2}{c}{$06 / 22 / 2004$} & \multicolumn{2}{c}{$08 / 04 / 2004$} & \multicolumn{2}{c}{ Student t-test } \\
Method & PS & CS & PS & CS & PS & CS & PS & CS & PS & CS & P \\
\hline Abundance (stained)) & 16844 & 10365 & 5855 & 6629 & 7709 & 4686 & 3720 & 10146 & 5257 & 10295 & 0.83 \\
Species richness (stained) & 12 & 14 & 8 & 8 & 7 & 8 & 11 & 9 & 8 & 7 & 0.99 \\
\hline Ammonia tepida & 12807 & 5688 & 4960 & 4184 & 7188 & 3218 & 2530 & 6956 & 3235 & 6806 & 0.74 \\
Brizalina striatula & 550 & 1338 & 448 & 363 & 52 & 428 & 174 & 797 & 168 & 294 & 0.08 \\
Cribroelphidium excavatum & 2459 & 658 & 224 & 1640 & 156 & 693 & 74 & 665 & 303 & 252 & 0.81 \\
Cribroelphidium gunteri & 330 & 82 & 37 & 0 & 52 & 142 & 223 & 310 & 1112 & 2438 & 0.43 \\
Haynesina germanica & 183 & 973 & 75 & 78 & 52 & 82 & 0 & 133 & 135 & 126 & 0.28 \\
Quinqueloculina seminula & 220 & 647 & 37 & 130 & 156 & 0 & 521 & 930 & 135 & 336 & 0.15
\end{tabular}


Appendix A. Benthic foraminifera: relative abundance of each species per sample according to depths in sediment cores sampled from 22 April to 4 August 2004 (“0”: relative abundances $>0$ and $<1$ per $50 \mathrm{~cm}^{3}$ of sediment).

\begin{tabular}{|c|c|c|c|c|c|c|c|c|c|c|c|c|c|c|c|c|c|c|c|c|c|c|c|c|c|}
\hline \multirow{2}{*}{$\begin{array}{l}\text { Sample date } \\
\text { Sample depth }(\mathrm{cm})\end{array}$} & \multicolumn{5}{|c|}{$04 / 22 / 2004$} & \multicolumn{5}{|c|}{ 05/25/2004 } & \multicolumn{5}{|c|}{\begin{tabular}{|c|}
$06 / 09 / 2004$ \\
\end{tabular}} & \multicolumn{5}{|c|}{$06 / 22 / 2004$} & \multicolumn{5}{|c|}{$08 / 04 / 2004$} \\
\hline & $0-0.5$ & $0.5-1$ & $1-3$ & $3-5$ & $5-8$ & $0-0.5$ & $0.5-1$ & $1-3$ & $3-5$ & $5-8$ & $0-0.5$ & $0.5-1$ & $1-3$ & $3-5$ & $5-8$ & $0-0.5$ & $0.5-1$ & $1-3$ & $3-5$ & $5-8$ & $0-0.5$ & $0.5-1$ & $1-3$ & $3-5$ & $5-8$ \\
\hline Ammonia tepida & 55 & 59 & 47 & 56 & 40 & 63 & 77 & 43 & 38 & 39 & 69 & 46 & 45 & 40 & 50 & 69 & 41 & 54 & 52 & 50 & 66 & 73 & 70 & 52 & 45 \\
\hline Bolivina pseudoplicata & 1 & . & . & . & . & . & . & . & . & . & . & . & . & . & . & . & . & . & . & . & . & . & . & . & . \\
\hline Brizalina cf. seminuda & . & . & . & . & . & . & . & . & . & . & . & 0 & . & . & . & . & . & . & . & . & . & . & . & 1 & . \\
\hline Brizalina sp. & . & . & . & . & . & . & . & . & . & . & . & 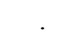 & . & . & . & . & 1 & . & . & . & . & . & . & . & . \\
\hline Brizalina spathulata & - & & . & & . & & . & . & . & . & . & 1 & . & . & . & . & . & . & . & . & & . & . & . & . \\
\hline Brizalina striatula & 13 & 6 & 6 & 3 & 4 & 5 & 7 & 7 & 15 & 4 & 9 & 13 & 10 & 3 & 3 & 8 & 4 & 14 & 5 & . & 3 & 7 & 8 & 9 & 5 \\
\hline Brizalina variabilis & . & . & 1 & & 1 & . & . & . & . & . & . & . & . & . & . & 1 & . & . & . & . & . & . & . & . & . \\
\hline Bulimina elegans & . & & . & & . & & 1 & . & . & . & 1 & 1 & . & 1 & . & & 1 & . & . & . & . & . & . & . & . \\
\hline Buliminella elegantissima & 1 & 1 & 0 & 1 & . & 1 & . & . & 6 & . & . & 3 & 1 & 0 & . & 2 & 1 & . & 2 & . & - & 1 & 1 & . & . \\
\hline Cribroelphidium excavatum & 6 & 15 & 27 & 25 & 40 & 25 & 11 & 37 & 28 & 44 & 15 & 29 & 30 & 51 & 36 & 7 & 48 & 16 & 19 & 35 & 2 & 16 & 16 & 25 & 35 \\
\hline Cribroelphidium gunteri & 1 & 7 & 11 & 6 & 10 & . & 1 & 4 & 13 & 10 & 3 & 3 & 10 & 5 & . & 3 & 1 & 10 & 15 & . & 24 & 1 & 3 & 8 & 10 \\
\hline Cribrostomoides jeffreysii & 0 & . & . & & . & . & . & . & . & . & . & . & . & . & . & . & . & . & . & . & . & . & . & . & . \\
\hline Eggerelloides scabrus & . & . & . & 3 & 1 & & 0 & . & . & . & 1 & . & . & . & . & . & . & . & . & . & . & . & . & . & . \\
\hline Fissurina lucida & . & . & . & & . & 1 & . & . & . & . & . & 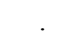 & . & . & . & . & . & . & . & . & . & . & . & . & . \\
\hline Fursenkoina sp. & . & . & . & . & . & . & 0 & . & . & . & . & 0 & . & . & . & . & . & . & . & . & . & . & . & . & . \\
\hline Gavelinopsis praegeri & . & 1 & 2 & . & . & . & . & . & . & . & . & . & . & . & 2 & . & . & . & . & 3 & . & . & . & . & . \\
\hline Haynesina germanica & 9 & 9 & 3 & 6 & 3 & 1 & 1 & 7 & . & 3 & 2 & 2 & 2 & . & 7 & 1 & . & . & 8 & 9 & 1 & 1 & 0 & 2 & 3 \\
\hline Hopkinsina pacifica & 1 & . & . & . & . & 1 & . & 2 & . & . & . & 1 & . & . & . & . & . & 2 & . & . & . & 0 & 1 & . & . \\
\hline Massilina secans & . & 1 & . & . & . & . & . & . & . & . & . & . & . & . & . & . & . & . & . & . & . & . & . & . & . \\
\hline Adelosina bicornis & . & . & . & . & . & . & . & . & . & . & . & . & . & . & . & . & . & 1 & . & . & - & . & . & . & . \\
\hline Quinqueloculina jugosa & . & & . & . & . & & . & . & . & . & . & . & . & . & . & 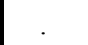 & . & . & . & . & 0 & . & . & . & . \\
\hline Quinqueloculina seminula & 6 & 1 & . & . & . & 2 & . & . & . & . & . & . & . & . & . & 9 & . & 4 & . & . & 3 & . & . & . & . \\
\hline Quinqueloculina sp. & . & . & . & 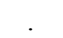 & . & . & . & . & . & & . & . & 1 & . & . & . & . & . & . & . & . & . & . & . & . \\
\hline Quinqueloculina stelligera & 3 & . & 1 & . & . & . & 1 & . & . & & 1 & . & . & . & 2 & . & . & . & . & 3 & . & . & . & . & . \\
\hline Reophax scorpiurus & 2 & . & 1 & . & . & . & . & . & . & . & . & . & . & . & . & . & . & . & . & . & . & . & . & . & . \\
\hline Rosalina cf. vilardeboana & . & . & . & . & . & . & . & 1 & . & . & . & . & . & . & . & . & . & . & . & . & . & . & . & . & . \\
\hline Spirillina vivipara & 0 & . & . & 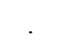 & . & . & . & . & . & & . & 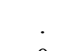 & . & . & . & . & . & . & . & . & . & . & . & . & . \\
\hline Spirobolivina sp. & . & . & . & & . & . & . & . & . & & . & 0 & . & . & . & 1 & . & . & . & . & . & . & . & . & . \\
\hline Stainforthia fusiformis & . & . & 1 & 1 & 1 & . & . & . & . & . & . & . & 2 & . & . & . & 1 & . & . & . & . & . & 1 & 2 & . \\
\hline Textularia earlandi & 1 & & & & & & & & & & & 1 & & 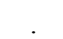 & & & & & & & & 1 & & . & \\
\hline
\end{tabular}


Appendix B. Taxonomic reference list. All taxa mentioned in the text and figures are included, together with citations of figured specimens that reflect the taxonomic concept followed here.

Illustration of most of the species could be found in Debenay et al. (2001) and Marine Pertuis

Database (www.ifremer.fr/lerpc/PGSauriau/foraminifera/indexforaminifera.htm).

Phylum Granuloreticulosa

Class Foraminifera

Order Foraminiferida

Suborder Textulariina

Cribrostomoides jeffreysii (Williamson, 1858); Marine Pertuis Database.

Eggerelloides scabrus (Williamson, 1858); Debenay et al. (2001), P1. I, Fig. 5.

Reophax scorpiurus de Monfort, 1808; Marine Pertuis Database.

Textularia earlandi Parker, 1952; Debenay et al. (2001), Pl. I, Fig. 6.

Suborder Spirillinina

Spirillina vivipara Ehrenberg, 1843; Debenay et al. (2001), P1. IV, Fig. 24.

Suborder Miliolina

Massilina secans (d'Orbigny, 1826); Debenay et al. (2001), Pl. II, Fig. 19.

Adelosina bicornis (Walker \& Jacob, 1798); Le Calvez \& Le Calvez (1958), Pl 4, Figs 28 and 32.

Quinqueloculina jugosa Cushman, 1944; Debenay et al. (2005), Pl. 1, Fig. 16.

Quinqueloculina seminula (Linné, 1758); Debenay et al. (2001), P1. II, Figs. 11-12.

Quinqueloculina stelligera Schlumberger, 1893; Debenay et al. (2001), P1. II, Figs. 3-4.

Suborder Lagenina

Fissurina lucida (Williamson, 1848); Debenay et al (2001), Pl. III, Fig. 27.

Suborder Rotaliina 
Ammonia tepida (Cushman, 1926); Marine Pertuis Database.

Bolivina pseudoplicata Heron-Allen \& Earland, 1930; Debenay et al. (2001), Pl. IV, Fig. 6.

Brizalina cf. seminuda (Cushman, 1911); Smith (Smith, 1963), P1 29, fig 1-7.

Brizalina spathulata (Williamson, 1858); Debenay et al. (2001), Pl. IV, Fig. 1.

Brizalina striatula (Cushman, 1922); Smith (1963), P1 30, fig 9-10

Brizalina variabilis (Williamson, 1858); Marine Pertuis Database.

Bulimina elegans d'Orbigny, 1826; Debenay et al. (2001), Pl. IV, Fig. 10.

Buliminella elegantissima (d'Orbigny, 1839); Debenay et al. (2001), Pl. IV, Fig. 16.

Cribroelphidium excavatum (Terquem, 1875); Debenay et al. (2001), P1. VI, Fig. 5.

Cribroelphdium gunteri (Cole, 1931); Marine Pertuis Database.

Gavelinopsis praegeri (Heron-Allen \& Earland, 1913); Debenay et al. (2001), Pl. V, Fig. 4.

Haynesina germanica (Ehrenberg, 1840); Debenay et al. (2001), Pl. VI, Fig. 11.

Hopkinsina pacifica Cushman, 1933; Debenay et al. (2001), Pl. IV, Fig. 14.

Rosalina cf. vilardeboana (d'Orbigny, 1839); Debenay et al. (2001), Pl. V, Fig. 11.

Stainforthia fusiformis (Williamson, 1848); Debenay et al. (2001), Pl. IV, Fig. 13. 